INTERNATIONAL

FOOD POLICY

RESEARCH

INSTITUTE

IFPRI

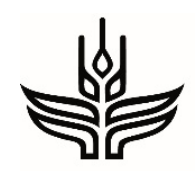

CGIAR and Markets

Led by IFPRI

IFPRI Discussion Paper 01869

September 2019

\title{
Can Transfers and Behavior Change Communication Reduce Intimate Partner Violence Four Years Post-program? \\ Experimental Evidence from Bangladesh
}

\author{
Shalini Roy \\ Melissa Hidrobo \\ John Hoddinott \\ Bastien Koch \\ Akhter Ahmed
}

Poverty, Health, and Nutrition Division 


\section{INTERNATIONAL FOOD POLICY RESEARCH INSTITUTE}

The International Food Policy Research Institute (IFPRI), established in 1975, provides research-based policy solutions to sustainably reduce poverty and end hunger and malnutrition. IFPRI's strategic research aims to foster a climate-resilient and sustainable food supply; promote healthy diets and nutrition for all; build inclusive and efficient markets, trade systems, and food industries; transform agricultural and rural economies; and strengthen institutions and governance. Gender is integrated in all the Institute's work. Partnerships, communications, capacity strengthening, and data and knowledge management are essential components to translate IFPRI's research from action to impact. The Institute's regional and country programs play a critical role in responding to demand for food policy research and in delivering holistic support for country-led development. IFPRI collaborates with partners around the world.

\section{AUTHORS}

Shalini Roy (s.roy@cgiar.org) is a Research Fellow in the Poverty, Health, and Nutrition Division of the International Food Policy Research Institute (IFPRI), Washington, DC.

Melissa Hidrobo (m.hidrobo@cgiar.org) is a Senior Research Fellow in the Poverty, Health, and Nutrition Division at IFPRI, Dakar, Senegal.

John Hoddinott (jfh246@cornell.edu) is the H.E. Babcock Professor of Food and Nutrition Economics and Policy in the Division of Nutrition Sciences at Cornell University, Ithaca, NY, and a Non-Resident Fellow at IFPRI.

Bastien Koch (b.koch@cgiar.org) is a Research Analyst in the Poverty, Health, and Nutrition Division at IFPRI, Washington, DC.

Akhter Ahmed (a.ahmed@cgiar.org) is a Senior Research Fellow in IFPRI’s Poverty, Health, and Nutrition Division and the Country Representative for IFPRI, Dhaka, Bangladesh.

\footnotetext{
Notices

${ }^{1}$ IFPRI Discussion Papers contain preliminary material and research results and are circulated in order to stimulate discussion and critical comment. They have not been subject to a formal external review via IFPRI's Publications Review Committee. Any opinions stated herein are those of the author(s) and are not necessarily representative of or endorsed by IFPRI.

${ }^{2}$ The boundaries and names shown and the designations used on the map(s) herein do not imply official endorsement or acceptance by the International Food Policy Research Institute (IFPRI) or its partners and contributors.

${ }^{3}$ Copyright remains with the authors. The authors are free to proceed, without further IFPRI permission, to publish this paper, or any revised version of it, in outlets such as journals, books, and other publication
} 


\title{
Can transfers and behavior change communication reduce intimate partner violence four years post-program? Experimental evidence from Bangladesh*
}

\author{
Shalini Roy ${ }^{\text {a }}$ \\ Melissa Hidrobo ${ }^{b}$ \\ John Hoddinott ${ }^{\mathrm{c}}$ \\ Bastien Koch ${ }^{\text {a }}$ \\ Akhter Ahmed ${ }^{\mathrm{d}}$
}

* This work was undertaken as part of the CGIAR Research Program on Policies, Institutions, and Markets (PIM) led by the International Food Policy Research Institute (IFPRI). Funding support for this study was provided by an anonymous donor, the World Food Programme, and the CGIAR Research Program on Policies, Institutions, and Markets. The study builds on research funded by the German Ministry for Economic Cooperation and Development (BMZ), the UK's Department for International Development (DFID), the Swiss Agency for Development and Cooperation (SDC), the United Nations Development Programme (UNDP), and the United States Agency for International Development (USAID).

a Poverty, Health, and Nutrition Division, International Food Policy Research Institute (IFPRI), Washington, DC, USA; ${ }^{b}$ Poverty, Health, and Nutrition Division, International Food Policy Research Institute (IFPRI), Dakar, Senegal; ' Division of Nutrition Sciences, Cornell University, Ithaca, New York, USA; ${ }^{\mathrm{d}}$ Poverty, Health, and Nutrition Division, International Food Policy Research Institute (IFPRI), Dhaka, Bangladesh.

` Corresponding author: s.roy@,cgiar.org, 1-202-862-4640. 


\begin{abstract}
Little is known about whether reductions in intimate partner violence (IPV) from cash transfer programs persist over the longer term. Using a randomized controlled trial design, we show that a program providing poor women in rural Bangladesh with cash or food transfers, alongside nutrition behavior change communication (BCC), led to sustained reductions in IPV 4 years after the program ended. Transfers alone showed no sustained impacts on IPV. Evidence suggests cash and BCC led to more sustained impacts on IPV than food and BCC - through persistent increases in women's bargaining power, men's costs of perpetrating violence, and poverty-related emotional well-being.
\end{abstract}

Keywords: Cash transfers, food transfers, behavior change communication, intimate partner violence, social protection, gender, sustainability, Bangladesh

JEL codes: J12, D10, I38, O10

\title{
Acknowledgments
}

We thank DATA for careful data collection and Wahid Quabili for excellent research assistance. All errors are our own. The study is registered with ClinicalTrials.gov (ID: NCT03810300), received ethical approval from the Institutional Review Board of the International Food Policy Research Institute (IFPRI), Washington, DC, and was reviewed by the Ministry of Food and Disaster Management in Bangladesh. 


\section{Introduction}

Widespread fears exist among program implementers that cash transfers targeted to women could put women at risk of violence from their partners - either due to men trying to take control of transfers or due to male backlash in response to shifting power dynamics (Cash Learning Partnership 2015; Mercy Corps 2015; World Bank 2019). A growing body of evidence, however, shows largely the opposite. Buller et al. (2018) review the literature on cash transfer programs and intimate partner violence (IPV) in low- and middle-income countries and find that, across 14 rigorous quantitative studies, over $70 \%$ show that a cash transfer program reduced IPV on average, despite IPV prevention not being an explicit objective of any of these. ${ }^{1}$ Given the multiple adverse consequences of IPV for women (Ellsberg et al. 2008; Kapiga et al. 2017) and their children (see Roy et al, forthcoming, for references) - along with the growing use of cash transfers in low- and middle-income countries where IPV is highly prevalent (Devries et al. 2013) - transfer programs are thus increasingly viewed as a promising platform for leveraging IPV prevention at scale.

However, core to the question of whether cash transfer programs can be a sustainable solution to reducing IPV is whether impacts persist after programs end - given that most beneficiaries do not receive cash transfers indefinitely. Evidence on the sustainability of cash transfers' impacts on IPV is scarce, as very few studies on cash and IPV collect post-program data. To date, only one study to our knowledge has done so - Roy et al. (forthcoming), in the context of a transfer program in Bangladesh called the Transfer Modality Research Initiative (TMRI). Roy et al. find that a combination of transfers and nutrition behavior change communication (BCC) leads to a sustained reduction in physical IPV - the first evidence of any 
post-program impact of transfers on IPV. However, they assess relatively short-term sustainability at 6-10 months post-program.

Moreover, although it is clear that impacts on pathways for IPV impacts must be sustained in order for impacts on IPV to continue post-program, there is also scarce evidence of cash transfers having persistent effects on outcomes related to these pathways. Buller et al. (2018) identify three pathways in the quantitative and qualitative literature through which cash transfers can affect IPV: (i) improved household economic well-being, (ii) reduced intrahousehold conflict, and (iii) improved women's empowerment. Although significant evidence demonstrates that cash transfers affect each of these (Buller et al. 2018), very few studies assess whether such impacts are sustained post-program. With respect to poverty, Stoeffler, Mills, and Premand (2016) show cash transfers have sustained impacts on assets and productive activities 18 months post-program in rural Niger. With respect to women's empowerment, Baird, McIntosh, and Özler (2019) show that most impacts of unconditional cash transfers to adolescent girls in Malawi dissipate at 2 years post-program, but some effects on educational attainment and number of births from conditional cash transfers are sustained. Roy et al. (forthcoming) show the impacts of TMRI's transfers and BCC on women's control over money and probability of working are sustained at 6-10 months post-program. Deeper understanding of the sustainability of impacts on these outcomes is critical, not only given their inherent importance but also given their relevance for informing design of future cash transfer programming for sustained IPV reduction.

In this paper, we address these evidence gaps. We assess the sustainability of impacts on IPV of TMRI in Bangladesh - the program studied by Roy et al. (forthcoming) - but do so 4 years after the program ended. We find that the reductions in physical IPV from a combination 
of transfers and $\mathrm{BCC}$ that were seen 6-10 months post-program by Roy et al. are sustained 4 years after the program ended. Evidence suggests that this is driven by sustained impacts from cash transfers with BCC, whereas impacts from food transfers with BCC appear to have faded. There are no sustained impacts on IPV from cash transfers alone or food transfers alone. To our knowledge, this is the first evidence of longer-term sustainability of IPV impacts, as well as the first evidence of IPV impacts differing by transfer modality.

We also extend the work by Roy et al. (forthcoming) by conducting careful analysis of the sustainability of mechanisms underlying IPV impacts 4 years post-program. We focus on three possible pathways adapted from Buller et al. (2018) based on TMRI's features: (i) improved women's bargaining power; (ii) increased men's cost of perpetrating violence; and (iii) improved poverty-related emotional well-being. Our analysis shows that, consistent with the pattern of IPV impacts, 4 years after TMRI ended, the combination of transfers and BCC leads to sustained impacts on all three of these pathways - increasing women's bargaining power as measured by their economic resources and agency, increasing men's costs of violence as measured by perceived social control, and improving poverty-related emotional well-being as measured by household-level consumption and men's emotional well-being. Suggestive evidence indicates that cash transfers with BCC affect more of these pathways than food transfers with BCC at 4 years post-program.

Our findings have important implications for program design. They show that a cash transfer program need not have IPV prevention as an explicit objective to result in sustained IPV reduction several years after the end of the program. However, it must lead to sustained impacts on pathways for IPV reduction. In the context of TMRI in Bangladesh, transfers combined with nutrition BCC lead to larger, broader impacts on these pathways 4 years post-program than 
transfers alone. Although we do not believe nutrition BCC per se is required in every cash transfer program in order for IPV reductions to be sustained, our findings highlight the importance of including some programming that - through its content or its structure, intended or unintended - sustainably affects IPV pathways.

More broadly, our analysis contributes to the scarce literature on the sustainability of impacts of cash transfer programs. The existing literature on post-program effects of cash transfer programs focuses almost exclusively on eventual human capital outcomes of individuals exposed during childhood (i.e., on cognitive or non-cognitive skills and labor market outcomes; see Millán et al. (2019)), providing little conclusive evidence on whether for example household poverty reduction - often the primary objective of cash transfers - is sustained. Moreover, much of this research draws on the United States (see Aizer et al. 2016; Hoynes, Schanzenbach, and Almond 2016) or Latin America (Araujo, Bosch, and Schady 2016; Barham, Macours, and Maluccio 2017; Behrman, Parker, and Todd 2015). Our evidence extends beyond the United States and Latin America to study South Asia, as well as expands beyond human capital outcomes to study the sustainability of impacts relevant to poverty, social norms, women's empowerment, and intrahousehold dynamics.

The paper is structured as follows. Section 2 presents the experimental design of the Transfer Modality Research Initiative and a conceptual framework to guide our analysis of the sustainability of its impacts on IPV. Section 3 outlines the data we use - including the measurement of IPV and an explanation of the pathways we consider; an assessment of the integrity of the experimental design; and a description of our estimation approach. Section 4 describes our main results on the sustainability of TMRI's impacts on IPV and potential pathways for these impacts. Section 5 provides a discussion of the results and concludes. 


\section{Program details and conceptual framework}

\subsection{The Transfer Modality Research Initiative}

\subsubsection{Experimental design}

The Transfer Modality Research Initiative (TMRI) was a 2-year pilot safety net program, implemented by the World Food Programme in rural Bangladesh from May 2012 to April 2014. It was based on two cluster-randomized controlled trials (RCTs): one in the northwest region (the "North") and one in the coastal southern region (the "South"). In the North, study villages were randomly assigned to a control group or to one of four treatment arms in which beneficiaries received cash transfers ("Cash"), food rations ("Food"), half cash transfers and half food rations (“Cash+Food"), or cash transfers along with nutrition BCC ("Cash+BCC"). In the South, study villages were also randomly assigned to a control group or to one of four treatment arms; the first three treatment groups were the same as in the north. In the fourth treatment group in the South, instead of cash transfers along with nutrition $\mathrm{BCC}$, beneficiaries received food rations along with nutrition BCC ("Food+BCC"). All beneficiaries were poor households with a child aged 0-24 months in March 2012. The mother of the child aged 0-24 months was the designated beneficiary - both the cardholder for receiving transfers and the target participant in BCC activities (see Ahmed et al. (2016) for more detail).

In each of the two regions, 250 villages were selected for inclusion in the study and were randomly assigned to one of the four treatment groups or control group for its region (see Appendix A). In each selected village, a census was conducted, from which a list was constructed of households that met the eligibility criteria for the study: that is, the household was considered poor (i.e., estimated to have consumption below the lower poverty line in 
Bangladesh); ${ }^{1}$ had a child aged 0-24 months in March 2012; and was not receiving benefits from any other social safety net interventions. From each village, 10 households meeting these three conditions were randomly selected for inclusion in TMRI. Thus, TMRI included a total of 5,000 targeted households across the North and South $-4,000$ treatment households and 1,000 control households.

\subsubsection{Transfers}

Beneficiaries in the "Cash" arms received a monthly payment of 1,500 Taka (approximately 19 USD) per household. Beneficiaries in the "Food" arms received a monthly food ration of 30 kilograms ( $\mathrm{kg}$ ) of rice, $2 \mathrm{~kg}$ of mosoor pulse (a lentil), and 2 liters of micronutrient-fortified cooking oil. These quantities were chosen so that the initial value of the food rations was equal to the value of the cash transfers of the beneficiaries in the "Cash" treatment arms. Beneficiaries in the "Cash+Food" treatment arms received half of each of the two types of transfers: 750 Taka, $15 \mathrm{~kg}$ of rice, $1 \mathrm{~kg}$ of mosoor pulse, and 1 liter of micronutrient-fortified cooking oil.

Cash and food transfers were delivered to women during the second week of every month. Cash was delivered using a mobile phone cash transfer system, in which women collected cash from designated distribution sites using mobile verification of identity. ${ }^{2}$ Food transfers were handed to beneficiaries at designated food distribution points. Cash and food

\footnotetext{
${ }^{1}$ The lower poverty line identifies the extreme poor households whose total household expenditures are below the estimated cost of a basic food basket providing 2,122 kilocalories per person per day.

${ }^{2}$ Since this method used a mobile phone handset and SIM card, to preserve the design of the experiment, these were provided to all women in the study (in all treatment and control arms).
} 
distribution points were no more than 2 kilometers from participants' homes (Ahmed et al. 2016).

\subsubsection{Behavior change communication}

The beneficiaries of the "Cash+BCC" arm in the North and the "Food+BCC" arm in the South received the same transfers as in the "Cash" only and "Food" only treatment groups, respectively, as well as a suite of intensive nutrition $\mathrm{BCC}$ interventions focused on education and behavior change at the household and community level (Ahmed et al. 2016). The BCC intervention involved three complementary activities: (1) weekly group BCC trainings - some with beneficiaries only (i.e., the target women in the Food+BCC or Cash+BCC groups) and some that invited other family members to attend along with beneficiaries, (2) twice-a-month visits to the beneficiaries' homes, and (3) monthly group meetings between program staff and influential community leaders.

The group BCC trainings only for beneficiaries occurred on the day of the transfer distribution, once a month. For the remaining group BCC trainings, other household members particularly mothers-in-law, husbands, and other pregnant or lactating women - were invited to attend along with beneficiaries, with the intention of creating a supportive household atmosphere and behavior change at the household level. These combined sessions served to facilitate women's ability to participate in the BCC, as household members could see what women were participating in and relax restrictions on attendance (given sociocultural norms of female seclusion), and to increase uptake of BCC messages as husbands and mothers-in-law are also key decision makers on food purchases, infant and young child feeding (IYCF) practices, and childrearing in the household. 
About 9-15 beneficiaries were part of each group. The group trainings took place no further than $2 \mathrm{~km}$ from beneficiaries' homes and lasted approximately one hour, on average. Beneficiaries assigned to a BCC intervention attended on average 48 of the scheduled 52 sessions per year in the North and 49 of the scheduled 52 sessions per year in the South. Trainings covered the following topics: basic nutrition, control and prevention of micronutrient deficiencies, IYCF, health care, maternal nutrition, and hygiene. The BCC training was led by female Community Nutrition Workers (CNWs) engaged by a local NGO specifically for TMRI. They were trained by WFP and the NGO to impart the BCC content using a variety of methods including question and answer, flashcards, real-life examples, discussions, practical demonstrations, role-playing, and songs. ${ }^{3}$ Anecdotally, the interactive nature of the sessions led to a lively atmosphere and solidarity among participants, who prior to the program had limited interaction outside the home and faced social exclusion in their communities. On field visits, researchers observed women arriving early at sessions and leaving late in order to talk with other members.

CNWs also conducted the twice-per-month home visits to observe household-level practice and encourage the adoption of positive behaviors, as well as followed up with home visits for individual counseling to beneficiaries on an as-needed basis. Attendance at the group BCC sessions was a soft condition of receipt of the transfers; when a mother missed a session, a CNW would follow up with a home visit to uncover what the reason was for missing the session

\footnotetext{
${ }^{3}$ The BCC component was designed specifically for TMRI by WFP in consultations with IFPRI and local technical experts. Session materials were derived in part from material developed for Alive \& Thrive (A\&T) in Bangladesh, a global nutrition initiative that seeks to save lives, prevent illness, and ensure healthy growth of mothers and children.
} 
and to convey the missed information, and no beneficiaries were dropped from the study for failing to attend sessions.

The monthly group meetings with influential community members (such as village heads, religious leaders, school teachers, community elected persons, and local health and family planning staff) were conducted by CNWs and staff from the local NGO, without the beneficiaries present, to explain the purpose and importance of the BCC and to provide them with the information being conveyed to study participants. Similar to why other household members were invited to group BCC trainings, these meetings aimed at facilitating women's participation and increasing uptake of messages through a supportive community environment.

Of note, there was no explicit focus on violence or gender issues in any of the BCC components. Interactive exercises included negotiating the purchase and consumption of nontraditional foods for pre-school children, but the emphasis was on how to acquire nutritious foods for the child rather than how to resolve conflict more generally.

\subsection{Conceptual framework}

For TMRI to have sustained impacts on IPV, it must have sustained effects on factors underlying IPV. To guide our analysis, we develop a conceptual framework of potential pathways for TMRI's sustained impacts on IPV. We first conceptualize pathways for how TMRI could affect IPV, then categorize different outcomes into "channels" that both underlie the various pathways and are potentially affected by TMRI.

We draw from the framework developed by Buller et al. (2018), which identifies three pathways supported by existing evidence for how cash transfer programs could affect IPV: i) improved economic security of the household and emotional wellbeing of its members; ii) 
reduced intrahousehold conflict between men and women; and iii) increased women's empowerment. The first is characterized by "increased financial and food security; increased savings, assets, and investments; and improved coping strategies" and relates to an emerging literature on the psychology of poverty, showing that poverty affects individuals' mental health and cognitive function (Haushofer and Fehr 2014; Mani et al. 2013), increasing stress and negative affective states that are risk factors for men perpetrating IPV. Thus, cash transfers may decrease IPV by reducing poverty, thereby reducing stress and improving the emotional wellbeing of household members including men. The second pathway is characterized by "increased availability of cash to meet daily needs" and focuses specifically on conflict that arises from stretched resources and tight budgets such as those that arise from women having to ask for money for daily needs when men do not have enough to give. Cash transfers may decrease IPV by reducing the scarcity of funds, thereby reducing arguments over spending money. Lastly, cash transfers that are targeted to women may decrease IPV by increasing women's empowerment, characterized as "enhanced self-confidence and self-efficacy, increased financial autonomy, and increased productive investments and activities." Women's increased empowerment shifts the power dynamics in a relationship, and men will either respond favorably and decrease IPV or unfavorably and increase IPV.

We make several adaptations to Buller et al.'s framework. First, we re-frame the “women's empowerment" pathway as "women's bargaining power." This focuses the pathway on aspects of empowerment that have a well-defined theoretical relationship with IPV. In noncooperative household bargaining models, individuals' bargaining power depends on their threat point, which is their out-of-marriage options or a non-cooperative equilibrium (Farmer and Tiefenthaler 1997; Tauchen, Witte, and Long 1991). If cash transfers are targeted to women and 
remain in their control, their income and thus their threat points increase, improving their bargaining power within the relationship to reduce IPV. Reframing as bargaining power also captures the notion that not all aspects of empowerment potentially affected by cash transfers will be sufficient to change intrahousehold dynamics in a way that reduces IPV. ${ }^{4}$

Second, we put more focus on the role of social capital. This modification is guided by the greater centrality of the group-based BCC component in TMRI than in the majority of cash transfer programming - and the observations of field staff regarding its effects on women's social interactions - as well as the importance of social capital for women in rural Bangladesh, where female seclusion norms prevail. Whereas Buller et al. represent social capital as one of several potential factors that could affect features of women's empowerment, we conceptualize social capital as an intrinsic component of women's bargaining power. Specifically, social ties could provide outlets for victims to escape violent relationships (Panda and Agarwal 2005; Stets 1991), making a women's threat point more credible.

Third, and related, we add a pathway that captures men's costs of inflicting IPV. Women's social capital factors into this pathway as well, as it increases the social cost of men's violent behavior by increasing the chances that violence is recognized by others and increases

\footnotetext{
${ }^{4}$ For example, a consumer durable jointly owned by the household may empower the woman but may not affect her bargaining power if she loses ownership by leaving the relationship or settling on a noncooperative equilibrium. Moreover, in rural South Asia, where "patriarchal risk" leaves women economically and socially vulnerable without guardianship of a male family member (Cain, Khanam, and Nahar 1979; Lentz 2018; Panda and Agarwal 2005), some dimensions of empowerment such as increased self-confidence may not alone be sufficient for women to reduce the level of IPV they are willing to accept.
} 
"social control" in the form of others' disapproval (Stets 1991; Van Wyk et al. 2003). ${ }^{5}$ We also conceptualize the private costs of men inflicting violence within this pathway, such as through potential changes in men's norms on the acceptability of violence. TMRI could change men's perception of the justifiability of IPV if, for example, seeing changes in women's mobility outside the home and other behavior due to $\mathrm{BCC}$ altered a descriptive or prescriptive norm among males in the community about the acceptability of these behaviors. ${ }^{6}$

Our final adaptation is to not explicitly consider the second pathway described in Buller et al. (reduced intrahousehold conflict between men and women) as distinct from the first pathway (economic security of the household and emotional wellbeing of its members). Conceptually, the pathways are distinct - they operate at the couple-level and household-level, respectively, and have potentially different predictions for changes in IPV. Empirically, however, they are challenging to distinguish. Reduced poverty underlies both, and it is difficult to disentangle which reductions in conflict are due directly to less stretched budgets and which are mediated by men's emotional well-being.

Thus, our conceptual framework for analyzing the sustainability of TMRI's impact on IPV has the following pathways: (i) women's bargaining power; (ii) men's cost; and (iii) poverty-related emotional well-being. Within women's bargaining power, channels include

\footnotetext{
${ }^{5}$ In Bangladesh Lentz (2018) documents that extended family, neighbors, and group members offer support to women and sometimes engage directly with their husbands about abuse. Brody et al. (2015) document several studies from South Asia that describe self-help groups taking action against domestic violence in their communities.

${ }^{6}$ Haushofer and Shapiro (2018) hypothesize a related dynamic to explain spillover effects of cash transfers on IPV in Kenya, wherein changes in the perceived prevalence and/or perceived justifiability of IPV among recipient households are believed to change norms in such a way that reduces IPV in non-recipient households.
} 
women's economic resources, women's agency, and women's social and community support all of which plausibly allow women to present a credible threat of leaving the relationship or settling on a noncooperative equilibrium. Within men's cost, channels include perceptions of social control as well as men's private costs of inflicting IPV. ${ }^{7}$ Within poverty-related emotional well-being, channels include household poverty and men's emotional well-being. The first two columns of Appendix Table 1 represent this framework.

\section{Data and estimation}

\subsection{Data collection}

Several rounds of quantitative longitudinal data have been collected on TMRI households. For the initial impact evaluation, three surveys were conducted: a baseline survey in March-April 2012 prior to the start of the intervention in May 2012, a midline survey in June 2013, and an endline survey in April 2014 just before the end of intervention. Then, to assess short-term sustainability of selected impacts as well as to measure IPV and early childhood development (ECD), a post-program survey was conducted from October 2014 to February 2015, 6 to 10 months after the intervention ended (denoted "6mPP" for "6 months post-program"). Finally, to assess longer-term sustainability of a range of impacts on households, women, and children, another post-program survey was conducted from April-May 2018, 4 years after the intervention ended (denoted “4yPP” for "4 years post-program”).

The baseline, midline, and endline surveys attempted to interview all 5,000 households that were included in TMRI treatment or control groups. At baseline, in each household, the

\footnotetext{
${ }^{7}$ As mentioned above, women's social and community support is also related to men's social cost of inflicting violence. For simplicity, in Appendix Table 1, we place this channel under women's bargaining power.
} 
youngest child aged 0-24 months in March 2012 was identified as the "index" child. At 6mPP, because measuring ECD was an objective and the selected ECD assessment was for children 30 months or older, the sample was restricted to households with index children aged at least 30 months by October 2014. Further, due to budget constraints, the $6 \mathrm{mPP}$ survey included a subset of the TMRI intervention arms - in the North, (1) Cash, (2) Cash+BCC, (3) Control; and in the South, (1) Food, (2) Food+BCC, (3) Control. The 4yPP survey included a larger subset of the TMRI intervention arms - in the North, (1) Cash, (2) Food, (3) Cash+BCC, (4) Control; and in the South, (1) Food, (2) Cash, (3) Food+BCC, (4) Control - and attempted to re-interview all households from the baseline survey in these arms.

In the baseline, midline, and endline rounds, multi-topic surveys were conducted in respondents' homes for the main impact evaluation of TMRI, but these did not include collection of IPV data. At $6 \mathrm{mPP}$, the index child and the child's mother (or if she was not available, the child's primary female caregiver) were requested to go to a village center (usually a school or community club) for ECD testing, after which interviewers administered a short instrument to the woman on several topics including the child's home environment and the woman's experience with IPV. At 4yPP, multi-topic surveys were again conducted in respondents' homes. Modules that measured experience with IPV or captured female information related to IPV pathways were preferentially asked of the index child's mother or other primary female caregiver if the mother was not available, as part of a "female questionnaire" administered by a female enumerator. Modules that captured male information related to IPV pathways were preferentially asked of the female respondent's husband (usually the household head and index child's father), as part of a "male questionnaire" administered by a male enumerator. 


\subsection{Outcomes}

\subsubsection{IPV}

The violence questions were drawn from the internationally validated standardized Intimate Partner Violence (IPV) modules in the WHO Violence Against Women instrument (Ellsberg and Heise 2005) and were administered following the WHO protocol on ethical guidelines for conducting research on women's experience with IPV (World Health Organization 2001). ${ }^{8}$ These modules ask multiple behaviorally-specific questions on a range of abusive acts, a technique shown to maximize disclosure (Ellsberg et al. 2001), over a period of the 12 months preceding the survey. We focused on two types of violence: emotional (4 questions) and physical (6 questions). For each act of violence, women were first asked if their current husband had ever done this. If they reported "yes," they were asked if it had occurred in the past 12 months; if they responded that it had, they were asked whether in the past 12 months it had occurred once, a few times, or many times.

The primary outcome measures we construct from these questions are indicators of (1) any emotional violence experienced in the past 12 months and (2) any physical violence experienced in the past 12 months. Each is coded as 1 if the woman responded that she had experienced any of the acts categorized as the respective type of violence (see Appendix B for the questions and categorizations) and 0 otherwise. These primary outcome measures are identical to the outcome measures used in the $6 \mathrm{mPP}$ survey except for the recall period, which

\footnotetext{
${ }^{8}$ This included ensuring adequate training of interviewers, guaranteeing privacy during interviews, ensuring informed consent and confidentiality of responses, interviewing only one woman per household so that other household members were not aware that survey questions involved IPV, and providing a referral for any disclosures of IPV.
} 
was 6 months at $6 \mathrm{mPP}$ in order to capture only the post-program period, whereas it is the standard 12 months at 4yPP. ${ }^{9}$

\subsubsection{Pathways for IPV impacts}

As outlined in Section 2.2, we conceptualize three hypothesized pathways for TMRI's sustained impacts on IPV: women's bargaining power, men's costs, and poverty-related emotional wellbeing. For our analysis, we listed variables in the 4yPP questionnaires that were relevant to each pathway and categorized them into 7 different channels: women's economic resources; women's agency; women's social and community support; perceived social control; men's private costs; household poverty; and men's emotional well-being. The final column of Appendix Table 1 shows how we map outcome variables across channels. Appendix Table 2 provides a detailed explanation of all outcome variables.

We aggregate outcome variables into summary indices at the level of each channel. Analyzing these summary indices instead of individual outcomes has several advantages (Anderson 2008). First, a summary index can approximate a measure of an underlying latent variable in ways a single outcome measure cannot. Second, aggregating outcomes into an index reduces the probability of a false discovery by reducing the number of distinct hypothesis tests conducted; the probability of false rejection does not increase as additional outcome variables are added to a summary index (Ibid.). We choose to aggregate at the level of channels rather than pathways, because the channels provide more insight into the dynamics of what impacts are

\footnotetext{
${ }^{9}$ The change in recall periods does not limit our ability to conduct impact estimation at $4 \mathrm{yPP}$ since comparisons are across intervention arms within the round, but it does mean prevalence estimated at $6 \mathrm{mPP}$ is not directly comparable with prevalence estimated at 4yPP.
} 
sustained and because one channel - women's social and community support - is relevant for two different pathways (women's bargaining power and men's cost).

Following Kling, Liebman, and Katz (2007) we aggregate the groups of outcome variables into standardized summary indices (channels), following the steps described in Appendix C. Each summary index has a mean of 0 and standard deviation of 1 for the control group, which means that the treatment effect estimates can be interpreted as the effect size relative to the control group, with higher scores representing more beneficial outcomes. As a robustness check, we also constructed summary indices using Inverse Covariance Weighting (ICW) following Anderson (2008). Further details on index construction are in Appendix C.

\subsection{Estimation sample}

Because our focus is on the sustainability at 4yPP of the IPV impacts found at $6 \mathrm{mPP}$, we start with the sample on which these impacts could be estimated at $6 \mathrm{mPP}$. At $6 \mathrm{mPP}$, the sampling frame of households with children aged at least 30 months by October 2014 from the selected three arms in the North and three arms in the South included 2,830 households. Of these, 2,749 pairs of children and women were successfully interviewed, with complete information on IPV. ${ }^{10}$ Of these 2,749 women, 2,430 or $88.4 \%$ were successfully re-interviewed on IPV at 4yPP. We drop women who had not been in the household at baseline, which consists of 14 women who

\footnotetext{
${ }^{10} \mathrm{In}$ the $6 \mathrm{mPP}$ study (Roy et al., forthcoming), the sample was further restricted to women who were already part of their household and married at baseline; who had non-missing information for their husbands at baseline; and who were respondents for the women's status modules at midline and endline, to allow drawing suggestive evidence on IPV pathways from previous rounds - yielding a final estimation sample of 2,231 women. Roy et al. show that IPV impacts were nearly identical between this sample and the larger sample of 2,749 women.
} 
were re-interviewed at 4yPP because they had accompanied the index child to the ECD testing at $6 \mathrm{mPP}$. The remaining 2,416 women constitute our final estimation sample, all of whom have baseline, 6mPP, and 4yPP data. We use this estimation sample to estimate IPV impacts at 4yPP, as well as impacts on channels at the level of the respondent women, their households, or their communities.

Amongst the 2,416 women, some have incomplete husband data. Even though 2,352 of the 2,416 women were still married at 4yPP (97.4\%, compared to $99.7 \%$ at baseline), 427 women have no husband data, because the husband was not in the household. Not all 427 women reported the reason for the husband having left the household, but among the 237 who did, $84 \%$ reported that their husbands left the household for work and $12 \%$ said their husbands had died (3\% other reasons). This leaves 1,989 women for whom we have complete husband data at 4yPP (Figure 1). All are married at 4-year post program, and 96.4\% said they had lived with their husband in the past 12 months. These 1,989 women are the sample on which we estimate impacts on channels related to men's emotional wellbeing and private cost of IPV.

\subsection{Attrition}

Attrition from the 2,749 women in the 6mPP sample to the 2,416 women in our 4yPP estimation sample is about $12 \%$ (or about $3 \%$ per year). Tables 1 and 2 show that, pooled across the two study regions, attrition does not systematically differ across intervention arms, and tests of joint orthogonality for baseline characteristics of women and households across arms fail to reject the null. Tables 1 and 3 show the same for the North. Tables 1 and 4 show that, for the South, attrition does not systematically differ between treatment arms and the control arm, but does differ between the Transfers and Transfers $+\mathrm{BCC}$ arms (13\% attrition in the Transfers arm vs. $8 \%$ 
in the Transfers $+\mathrm{BCC}$ arm, $\mathrm{p}$-value $=0.03$ ); a test of joint orthogonality between the Food $+\mathrm{BCC}$ arm and the control has a marginally significant p-value of 0.06 . Overall, the validity of our experimental design appears intact in the final 4yPP estimation sample, though the results in the South suggest a possibility of nonrandom selection into the estimation sample; we consider the implications of this in Section 4.2. Appendix Table 3 and Appendix Table 4 further show that, in terms of attrition and baseline balance, when comparing the 2,749 women at $6 \mathrm{mPP}$ to the sample of 1,989 women for whom impacts on husband-level channels can be estimated at 4yPP, there are no significant differences across intervention arms, pooled or by region.

\subsection{Estimation strategy}

Using 4yPP data, we conduct an intent-to-treat (ITT) analysis using single-difference estimation. The randomized assignment and balance in baseline characteristics reduce concerns of bias in the single-difference treatment estimates. To increase the sample size - and thereby the statistical power of the analysis - we pool the RCTs in the North and South (Bourey et al. 2015) and create three intervention arms: a "Transfers" treatment (Cash in the North or Food in the South), a "Transfers+BCC" treatment (Cash+BCC in the North or Food+BCC in the South), and a pooled control group (Control in the North or the South).

In our base estimation, we take into account the study design and control for the level of stratification. Since the main IPV outcomes of interest are binary, with $Y_{i v t}=1$ if the woman reported experiencing IPV and $Y_{i v t}=0$ if not, we estimate the following probit model for woman $i$ from village $v$ at period $t$ :

$$
\operatorname{Prob}\left(Y_{i v t}=1\right)=\Phi\left(\propto+\beta_{1} \text { Transfers }_{v}+\beta_{2}{\text { Transfers } B C C_{v}}+\delta R_{i v}\right)
$$


where $\Phi$ is the cumulative distribution function of the standard normal distribution. Period $t$ denotes that we estimate the equation for both $6 \mathrm{mPP}$ and $4 \mathrm{yPP}$ separately to assess whether impacts on IPV persist after 6mPP. $R_{i v}$ is an indicator for the study region, which is the level of stratification. The indicator Transfers $s_{v}$ equals one if village $v$ is assigned to the Food or Cash treatment arms, and $\beta_{1}$ represents the ITT estimator, or the effect of being assigned to the Transfers arm relative to the control group, which is the omitted category. Likewise, the indicator TransfersBCC $v$ equals one if village $v$ is assigned to the Food+BCC or Cash+BCC treatment arms, and $\beta_{2}$ represents the ITT estimator, or the effect of being assigned to a Transfers $+\mathrm{BCC}$ arm relative to the control group. To test whether $\beta_{1}$ and $\beta_{2}$ are statistically different from each other, we conduct Wald tests of equality and report the p-values. Coefficients from probit models are converted to average marginal effects. Finally, in all regressions we adjust standard errors for clustering at the village level - the level of randomization.

We then estimate a specification with extended baseline control variables, adding baseline characteristics of the woman and her household. Adding these covariates helps increase the precision of the estimates and control for any minor differences between intervention arms at baseline. They include the female respondent's characteristics (whether she is the spouse of the household head, whether she can read and write, her years of education, her age, her number of children 0-5 years old in the household, her number of children 6-15 years old in the household), and total household size.

For discrete outcomes such as frequency of IPV, or continuous outcomes such as IPV channels (z-scores), we use standard ordinary least squares (OLS) regressions and use an analogous specification to the above with extended controls. 


\section{Results}

\subsection{Main IPV results}

Assessing sustainability of TMRI's impacts on IPV implies comparing the impacts at 4yPP with impacts at $6 \mathrm{mPP}$ on the same sample. In Table 5, we estimate 4yPP impacts pooled across North and South, as well as re-estimate impacts at $6 \mathrm{mPP}$ on the sample used at 4yPP. There are no significant impacts of Transfers alone or Transfers $+\mathrm{BCC}$ on emotional violence at either $6 \mathrm{mPP}$ or 4yPP. Transfers alone have no impact on physical violence in either time period. By contrast, there are large and significant impacts of Transfers $+\mathrm{BCC}$ on physical violence both at $6 \mathrm{mPP}$ and 4yPP. The magnitude of the impact - 6 to 7 percentage points (about a 29 to 33 percent reduction relative to the control) - does not change over time, and a specification interacting treatments with $6 \mathrm{mPP}$ or $4 \mathrm{yPP}$ confirms that the coefficients do not statistically differ across rounds, suggesting that impacts are sustained between $6 \mathrm{mPP}$ and $4 \mathrm{yPP}$. The difference in impact between Transfers only and Transfers $+\mathrm{BCC}$ is large and significant at $6 \mathrm{mPP}$ and at $4 \mathrm{yPP}$, suggesting that linking the transfers to $\mathrm{BCC}$ is required for post-program impacts in both time periods.

We next examine whether sustainability differs by region and transfer modality, by disaggregating the above impacts between the North and the South. Table 6 reveals that the sustainability of IPV impacts from Transfers $+\mathrm{BCC}$ at $4 \mathrm{yPP}$ is driven almost exclusively by Cash+BCC in the North. Whereas at $6 \mathrm{mPP}$, the difference in impacts on physical IPV between Cash $+\mathrm{BCC}$ in the North and Food $+\mathrm{BCC}$ in the South was not statistically significant, at 4yPP this difference is highly significant. In the North, Cash+BCC leads to significant decreases in physical violence of 9 percentage points at $6 \mathrm{mPP}$ and 14 percentage points at $4 \mathrm{yPP}$. These are large impacts that represent 30 and 54 percent reductions respectively compared to the control 
mean. There are no impacts from Cash only in the North at either $6 \mathrm{mPP}$ or $4 \mathrm{yPP}$, and the differences in impact on physical violence across Cash and Cash $+\mathrm{BCC}$ are significant at both 6mPP and 4yPP. By contrast, the difference in impact on physical violence across Food and Food $+\mathrm{BCC}$, while borderline significant at $6 \mathrm{mPP}$, is no longer significant at $4 \mathrm{yPP}$, and point estimates for both arms are near zero at 4yPP, implying that impacts were sustained at $6 \mathrm{mPP}$ but faded out by $4 \mathrm{yPP}$.

\subsection{Robustness}

We check the robustness of our results in several different ways. First, we note that results in Table 5 are robust to the inclusion of covariates, as reflected by comparison of the basic control estimates and extended control estimates. Second, Appendix D shows that the 4yPP findings are robust to using alternative measures of violence - indicators for the individual acts of IPV and indicators of frequency of violence that capture the intensive margin.

Next, to address potential non-random selection into our estimation sample - of particular relevance for the South - we follow Lee (2009) and bound our estimates by trimming the upper and bottom tails of the distribution of the main IPV outcomes at 4yPP. Appendix Tables 7 to 9 show point estimates as well as upper bound and lower bound estimates for each comparison. ${ }^{11}$ In the pooled sample and in each region, the bounds are narrow and, in many cases, identical to the point estimates due to low differential attrition between the treatment groups, indicating that non-random attrition does not drive results.

We note that social desirability bias - the tendency to provide answers deemed to be viewed favorably by others - should not differentially affect our results from Transfers + BCC

\footnotetext{
${ }^{11}$ Each comparison is a different regression. Thus, point estimates may differ slightly from those in Table 5.
} 
arms because the BCC component of TMRI focused on nutrition, not gender issues or intrahousehold conflict. If social desirability bias led to similar under-reporting of IPV across all treatment and control groups, it would not bias our impact estimates. But as an additional robustness check, we assess how social desirability bias might affect our results, using a subset of five binary questions adapted from the short form of the Marlowe-Crowne social desirability scale (Reynolds 1982) and following the method outlined in Menon et al. (2016). Our findings in Appendix E suggest that our main results are unlikely to be driven by social desirability bias.

Lastly, we adjust our inference for multiple hypothesis testing by controlling the false discovery rate using two alternative methods (Benjamini, Krieger, and Yekutieli 2006; Benjamini and Hochberg 1995). Appendix Tables 15 and 16 show that our results are robust to these adjustments.

\subsection{Pathways}

Guided by the framework in Section 2.2, we next analyze whether TMRI led to sustainable impacts on seven channels that potentially underpin our impact results- women's economic resources; women's agency; women's social and community support; perceived social control; men's private costs; household poverty; and men's emotional well-being. ${ }^{12}$

Table 7 reports impact estimates on each channel at 4yPP, pooled across the two RCTs. Consistent with the 4yPP impacts found on IPV, Transfers+BCC lead to sustained impacts at 4yPP on several channels linking TMRI to IPV, while Transfers alone do not. At 4yPP, Transfers+BCC lead to significant improvements in women's economic resources $(0.11$ standard deviations) and women's agency (0.17 standard deviations), which underlie increases in

\footnotetext{
12 These channels reflect those for which we have evidence and are not necessarily exhaustive.
} 
women's bargaining power. Transfers $+\mathrm{BCC}$ also sustainably increase men's costs of violence, by raising men's social cost (as captured by perceived social control) though not their private cost (as measured by their personal norms and attitudes). Transfers+BCC sustainably affect poverty-related emotional well-being, through significant reductions in household poverty $(0.27$ standard deviations) and significant improvements in men's emotional well-being (0.14 standard deviations). As with the IPV results, impacts on several channels are significantly different for Transfers and Transfers $+\mathrm{BCC}$, suggesting that the $\mathrm{BCC}$ contributes to sustained impacts on pathways. Results are robust to a restricted sample of women for whom we have husband data (Appendix Table 17) as well as to the Inverse Covariance Weighting approach (Anderson 2008) used as an alternative method of constructing the indices, as shown in Appendix Table 18.

We next assess whether these pathways differ by region and transfer modality. Table 8 reveals that, consistent with the 4yPP impacts on IPV, 4yPP impacts on channels for IPV are driven by Cash $+\mathrm{BCC}$ in the North. Overall, 4yPP impacts on channels are stronger and have more breadth in the North than in the South and from arms with BCC than from arms without BCC. Specifically, Cash+BCC in the North leads to statistically significant positive impacts across the channels of women's economic resources, women's agency, women's social and community support, household poverty, and men's emotional wellbeing - which, together, underlie all three pathways. By contrast, there is only one borderline significant positive impact of Food $+\mathrm{BCC}$ in the South, which is on perceived social control. These results are largely robust to adjustments for multiple testing (Appendix Table 19). Point estimates are larger for Cash + BCC in the North than Food + BCC in the South for all channels besides perceived social control - and these differences are significant or borderline significant for women's social and community support, men's private costs, household poverty, and men's emotional well-being. 
We note that in the North there are also positive impacts from Cash on women's agency, household poverty, and men's emotional well-being, although these are smaller than from Cash + BCC and significantly different for household poverty. Taken together, the comparison of pathways impacted by Cash $+\mathrm{BCC}$ in the North, Food $+\mathrm{BCC}$ in the South, and Cash in the North suggests that broad impacts on channels may be needed for sustainable reductions in IPV.

\section{Discussion and conclusions}

We find that reductions in physical IPV from the combination of Transfers $+\mathrm{BCC}$ at 6 months post-program (Roy et al., forthcoming) are sustained 4 years after the program ended. Impacts represent 6 to 7 percentage point decreases (about 29 to 33\%) relative to the control group and are the first evidence of longer-term sustainability of transfers' impacts on IPV. Results are driven by the Cash+BCC arm in the North. At 4yPP, Cash+BCC in the North causes a large 14 percent reduction (about 54\%) in physical IPV relative to the control. Cash in the North, Food in the South, and Food $+\mathrm{BCC}$ in the South have no significant impacts on physical IPV at $4 y P P$.

We go beyond the results found in Roy et al. (forthcoming) by systematically considering the pathways and channels that underpin these impacts. Our pooled estimates show sustained impacts of TMRI's Transfers+BCC on several conceptualized channels for IPV reduction:

women's economic resources, women's agency, perceived social control, household poverty, and men's emotional well-being. By contrast, there are no sustained impacts on the channels from Transfers only. These findings give considerable credibility to our core findings on sustained impacts on IPV, as we are able to show evidence of sustained impacts on pathways that underlie these reductions. Consistent with the IPV impacts, impacts on channels at 4yPP are driven by Cash + BCC in the North. Cash + BCC in the North improves women's economic resources, 
women's agency, women's social and community support, household poverty, and men's emotional well-being - channels that span all three pathways. By contrast, Food+BCC in the South has only a borderline significant positive impact on perceived social control. While Cash in the North also significantly improves women's agency, household poverty, and men's emotional well-being, we do not see significant impacts on IPV from Cash alone in the North. These findings indicate that impacts on multiple channels may be needed for sustained impacts on IPV, possibly because in this study context there are multiple constraints to reducing IPV.

Given that Roy et al. (forthcoming) found both Cash+BCC in the North and Food+BCC in the South led to sustained reductions in physical IPV at $6 \mathrm{mPP}$, our findings raise the question of why at 4yPP only Cash $+\mathrm{BCC}$ in the North reduces IPV. One possibility is that the modality is key - that is, cash is more effective in the longer term than food in improving IPV channels when combined with BCC. Although we cannot test this directly, Table 8 shows that Cash alone in the North shows stronger impacts on channels than Food alone in the South - suggesting that cash may be more likely to sustain impacts on pathways in the longer term, particularly with respect to women's economic resources, women's agency, and household poverty. This is plausible if cash is better able to mobilize productive investments. A second possibility is that context is key - that is, differences in "initial conditions" (or conditions in the absence of intervention, as reflected by the control group) determine effects on channels. Again, although we cannot test this directly, we note in Table 8 that, for each channel, a larger impact is found in the region where the initial condition is "worse." Plausibly, both modality and context contribute to our findings: cash may be expected to have more sustained impacts on channels affecting IPV than food in the longer term - particularly for channels related to economic outcomes - and a 
context with worse initial conditions in terms of these channels may be expected to show larger effects from intervention due to greater potential to benefit.

A related point is that we can conclude the differences at $4 \mathrm{yPP}$ between Cash+BCC in the North and Food+BCC in the South are not due to a difference in the BCC itself, as this component was highly standardized and had nearly identical participation in North and South (Roy et al., forthcoming). This suggests that BCC alone would not have led to sustained reductions at 4yPP - if it were to have, then the North and South would have both shown impacts at $4 \mathrm{yPP} \cdot{ }^{13}$ Also notable is that women's social and community support no longer appears affected by Food + BCC in the South at 4yPP while it is by Cash $+\mathrm{BCC}$ in the North. Given evidence during the TMRI program of increased social interaction in both the North and South, with no significant differences between regions (Hoddinott et al. 2017), this raises the question of why the effect seems to have faded out over time only in the South. One possibility is that reduced poverty was required for sustaining the improvement in women's social and community support - for example, that without sustained improvements in household economic well-being, which do not appear in the Food+BCC arm in the South, women went back to being socially excluded. Again, this suggests potential complementarity across channels.

We end with several interlinked observations. First, in our study context, programming that complements social protection appears critical for sustaining impacts on IPV - and moreover, for sustaining impacts on the pathways underlying IPV. ${ }^{14}$ But complementary programming does not guarantee sustained impacts on IPV or its channels over the longer term.

\footnotetext{
${ }^{13}$ This could not be definitively shown from the 6mPP study, as Cash+BCC and Food+BCC both showed impacts.

${ }^{14}$ Although it is likely that transfers alone reduced IPV during the program (Roy et al., forthcoming), they no longer had significant impacts on physical IPV at either 6mPP or 4yPP.
} 
Within the same country, with identical BCC, with identical-value transfers, the impacts at 4yPP come from combining $\mathrm{BCC}$ with cash in the North but largely not from combining $\mathrm{BCC}$ with food in the South. Second, our 4yPP analysis provides convincing evidence that a transfer of meaningful magnitude was also critical, implying BCC alone (although we did not test this modality) would not have led to sustained reductions in physical IPV at 4yPP. Third, suggestive evidence points to a role for the modality of the transfer. Although we cannot conclusively distinguish the effects of cash vs. food from North vs. South, results indicate that when combined with BCC, cash may better sustain reductions in IPV over the longer term. This contrasts with the shorter-term findings of Hidrobo, Peterman, and Heise (2016) during a transfer program in Ecuador and Roy et al. (forthcoming) at 6mPP in Bangladesh, both of which showed that transfer modality did not matter for IPV impacts in these time periods. Fourth, suggestive evidence points to a role for context. Impacts on channels are larger at $4 \mathrm{yPP}$ in the regions where the control group is worse in terms of the channel. Finally, our findings suggest impacting multiple channels and/or pathways may be needed in order to lead to sustained reductions in IPV. This is an area for future research. 


\section{Tables}

Table 1: Attrition from $6 \mathrm{mPP}(\mathrm{N}=\mathbf{2 , 7 4 9 )}$ to $4 \mathrm{yPP}(\mathrm{N}=\mathbf{2 , 4 1 6})$

\begin{tabular}{|c|c|c|c|}
\hline & Full sample & North & South \\
\hline \multirow[t]{2}{*}{ Transfers } & 0.01 & -0.01 & 0.04 \\
\hline & $(0.02)$ & $(0.02)$ & $(0.03)$ \\
\hline \multirow{2}{*}{ Transfers $+\mathrm{BCC}$} & -0.00 & 0.01 & -0.01 \\
\hline & $(0.02)$ & $(0.03)$ & $(0.02)$ \\
\hline \multirow[t]{2}{*}{ Constant/Control group } & 0.10 & 0.14 & 0.09 \\
\hline & $(0.01)^{* * *}$ & $(0.02)^{* * *}$ & $(0.02)^{* * *}$ \\
\hline$R^{2}$ & 0.00 & 0.00 & 0.00 \\
\hline$N$ & 2,749 & 1,374 & 1,375 \\
\hline P-value: Transfers $=$ Transfers $+\mathrm{BCC}$ & 0.41 & 0.44 & 0.03 \\
\hline
\end{tabular}

LS coefficients reported. Full sample model includes regional fixed effects (not shown).

Standard errors are clustered at the village level. * $p<0.1 * * p<0.05$; *** $p<0.01$ 
Table 2: Baseline characteristics by intervention arm

\begin{tabular}{|c|c|c|c|c|c|c|c|}
\hline & \multirow[t]{2}{*}{$\mathrm{N}$} & \multicolumn{3}{|c|}{ Means } & \multicolumn{3}{|c|}{ P-value of diff. } \\
\hline & & Transfers & Transfers $+\mathrm{BCC}$ & Control & $\begin{array}{l}\text { Transfers - } \\
\text { Control }\end{array}$ & $\begin{array}{c}\text { Transfers }+\mathrm{BCC}- \\
\text { Control }\end{array}$ & $\begin{array}{c}\text { Transfers - } \\
\text { Transfers+BCC }\end{array}$ \\
\hline Female respondent's age & 2,416 & 27.32 & 27.08 & 27.33 & 0.98 & 0.50 & 0.50 \\
\hline Female respondent's education (years) & 2,416 & 3.19 & 3.25 & 3.53 & 0.11 & 0.22 & 0.77 \\
\hline Female respondent can read and write & 2,416 & 0.54 & 0.57 & 0.58 & 0.24 & 0.70 & 0.48 \\
\hline Female respondent is spouse of $\mathrm{HH}$ head & 2,416 & 0.77 & 0.76 & 0.78 & 0.71 & 0.52 & 0.78 \\
\hline Number of children $0-5$ years (of respondent) & 2,416 & 1.37 & 1.34 & 1.35 & 0.60 & 0.72 & 0.39 \\
\hline Number of children $6-15$ years (of respondent) & 2,416 & 0.97 & 0.90 & 0.95 & 0.78 & 0.44 & 0.30 \\
\hline Household size & 2,416 & 5.21 & 5.15 & 5.26 & 0.62 & 0.27 & 0.55 \\
\hline$p$-value from joint $F$-test & & & & & 0.78 & 0.34 & 0.93 \\
\hline
\end{tabular}

P-values are reported from Wald tests on the equality of means of control and each treatment for each variable.

Standard errors are clustered at the village level. $* p<0.1 * * p<0.05 ; * * * p<0.01$ 
Table 3: Baseline characteristics by intervention arm, North

\begin{tabular}{|c|c|c|c|c|c|c|c|}
\hline & \multirow[t]{2}{*}{$\mathrm{N}$} & \multicolumn{3}{|c|}{ Means } & \multicolumn{3}{|c|}{ P-value of diff. } \\
\hline & & Cash & $\mathrm{Cash}+\mathrm{BCC}$ & Control & $\begin{array}{l}\text { Cash - } \\
\text { Control }\end{array}$ & $\begin{array}{c}\text { Cash }+ \text { BCC } \\
\text {-Control }\end{array}$ & $\begin{array}{c}\text { Cash - } \\
\text { Cash+BCC }\end{array}$ \\
\hline Female respondent's age & 1,181 & 27.10 & 27.51 & 27.29 & 0.68 & 0.67 & 0.41 \\
\hline Female respondent's education (yrs) & 1,181 & 2.85 & 2.75 & 2.96 & 0.70 & 0.47 & 0.72 \\
\hline Female respondent can read and write & 1,181 & 0.49 & 0.48 & 0.48 & 0.87 & 0.91 & 0.96 \\
\hline Female respondent is spouse of $\mathrm{HH}$ head & 1,181 & 0.82 & 0.82 & 0.82 & 0.90 & 0.86 & 0.96 \\
\hline Number of children $0-5$ years of respondent & 1,181 & 1.34 & 1.35 & 1.37 & 0.63 & 0.68 & 0.98 \\
\hline Number of children 6-15 years of respondent & 1,181 & 0.86 & 0.96 & 0.86 & 0.91 & 0.20 & 0.24 \\
\hline Household size & 1,181 & 4.97 & 5.04 & 4.97 & 0.99 & 0.53 & 0.56 \\
\hline $\mathrm{p}$-value from joint $\mathrm{F}$-test & & & & & 0.79 & 0.43 & 0.92 \\
\hline
\end{tabular}

P-values are reported from Wald tests on the equality of means of control and each treatment for each variable.

Standard errors are clustered at the village level. $* p<0.1 * * p<0.05 ; * * * p<0.01$ 
Table 4: Baseline characteristics by intervention arm, South

\begin{tabular}{|c|c|c|c|c|c|c|c|}
\hline & \multirow[t]{2}{*}{$\mathrm{N}$} & \multicolumn{3}{|c|}{ Means } & \multicolumn{3}{|c|}{ P-value of diff. } \\
\hline & & Food & Food + BCC & Control & $\begin{array}{l}\text { Food - } \\
\text { Control }\end{array}$ & $\begin{array}{c}\text { Food }+ \text { BCC } \\
\text {-Control }\end{array}$ & $\begin{array}{c}\text { Food - } \\
\text { Food+BCC }\end{array}$ \\
\hline Female respondent's age & 1,235 & 27.53 & 26.70 & 27.36 & 0.74 & 0.20 & $0.10^{*}$ \\
\hline Female respondent's education (yrs) & 1,235 & 3.54 & 3.71 & 4.07 & $0.06^{*}$ & 0.23 & 0.56 \\
\hline Female respondent can read and write & 1,235 & 0.60 & 0.64 & 0.67 & $0.06^{*}$ & 0.41 & 0.34 \\
\hline Female respondent is spouse of $\mathrm{HH}$ head & 1,235 & 0.71 & 0.70 & 0.74 & 0.51 & 0.38 & 0.79 \\
\hline Number of children $0-5$ years of respondent & 1,235 & 1.40 & 1.34 & 1.34 & 0.19 & 0.95 & 0.17 \\
\hline Number of children 6-15 years of respondent & 1,235 & 1.08 & 0.86 & 1.05 & 0.75 & $0.06^{*}$ & $0.03 * *$ \\
\hline Household size & 1,235 & 5.46 & 5.26 & 5.54 & 0.57 & $0.06^{*}$ & 0.17 \\
\hline $\mathrm{p}$-value from joint $\mathrm{F}$-test & & & & & 0.46 & $0.06^{*}$ & 0.29 \\
\hline
\end{tabular}

P-values are reported from Wald tests on the equality of means of control and each treatment for each variable

Standard errors are clustered at the village level. ${ }^{*} p<0.1 * * p<0.05 ; * * * p<0.01$ 
Table 5: 4-year post-program impact of treatment on prevalence of IPV in past 12 months, pooled North and South

\begin{tabular}{|c|c|c|c|c|c|c|c|c|}
\hline & \multirow[b]{2}{*}{$\mathrm{N}$} & \multirow[b]{2}{*}{$\begin{array}{c}\text { Mean } \\
\text { of } \\
\text { Control }\end{array}$} & \multicolumn{3}{|c|}{ Basic controls } & \multicolumn{3}{|c|}{ Extended controls } \\
\hline & & & Transfers & $\begin{array}{c}\text { Transfers } \\
+\mathrm{BCC}\end{array}$ & $\begin{array}{c}\text { P-value of } \\
\text { Transfers= } \\
\text { Transfers }+ \\
\text { BCC }\end{array}$ & Transfers & $\begin{array}{c}\text { Transfers } \\
+\mathrm{BCC}\end{array}$ & $\begin{array}{c}\text { P-value of } \\
\text { Transfers }= \\
\text { Transfers }+ \\
\text { BCC }\end{array}$ \\
\hline Emotional violence (last6m) at 6mPP & 2,416 & 0.62 & $\begin{array}{c}0.01 \\
(0.04)\end{array}$ & $\begin{array}{l}-0.02 \\
(0.04)\end{array}$ & 0.44 & $\begin{array}{c}0.01 \\
(0.04)\end{array}$ & $\begin{array}{l}-0.02 \\
(0.04)\end{array}$ & 0.42 \\
\hline Emotional violence (last $12 \mathrm{~m}$ ) at $4 \mathrm{yPP}$ & 2,416 & 0.42 & $\begin{array}{c}0.02 \\
(0.03)\end{array}$ & $\begin{array}{l}-0.03 \\
(0.03)\end{array}$ & 0.11 & $\begin{array}{c}0.02 \\
(0.03)\end{array}$ & $\begin{array}{l}-0.03 \\
(0.03)\end{array}$ & $0.08 *$ \\
\hline Physical violence (last6m) at $6 \mathrm{mPP}$ & 2,416 & 0.26 & $\begin{array}{c}0.00 \\
(0.02)\end{array}$ & $\begin{array}{l}-0.06^{* * *} \\
(0.02)\end{array}$ & $0.01 * *$ & $\begin{array}{l}-0.00 \\
(0.02)\end{array}$ & $\begin{array}{l}-0.07 * * * \\
(0.02)\end{array}$ & $0.01 * *$ \\
\hline Physical violence (last $12 \mathrm{~m}$ ) at $4 \mathrm{yPP}$ & 2,416 & 0.21 & $\begin{array}{l}-0.03 \\
(0.02)\end{array}$ & $\begin{array}{l}-0.06^{* * * *} \\
(0.02)\end{array}$ & $0.08^{*}$ & $\begin{array}{l}-0.03 \\
(0.02)\end{array}$ & $\begin{array}{l}-0.07 * * * \\
(0.02)\end{array}$ & $0.05^{* *}$ \\
\hline
\end{tabular}

Marginal effects of probit models reported. Extended controls include baseline characteristics of the woman and her household.

Standard errors clustered at the village level. * $p<0.1 * * p<0.05 ; * * *<<0.01$ 
Table 6: 4-year post-program impact of treatment on prevalence of IPV in the past 12 months, North vs. South

\begin{tabular}{|c|c|c|c|c|c|c|c|c|c|c|}
\hline & \multicolumn{4}{|c|}{ North } & \multicolumn{4}{|c|}{ South } & \multicolumn{2}{|c|}{ North versus South } \\
\hline & $\begin{array}{c}\text { Mean } \\
\text { of } \\
\text { Control }\end{array}$ & Cash & $\mathrm{Cash}+\mathrm{BCC}$ & $\begin{array}{c}\text { P-value of } \\
\text { Cash }= \\
\text { Cash+BCC }\end{array}$ & $\begin{array}{c}\text { Mean } \\
\text { of } \\
\text { Control }\end{array}$ & Food & Food+BCC & $\begin{array}{c}\text { P-value of } \\
\text { Food }= \\
\text { Food+BCC }\end{array}$ & $\begin{array}{c}\text { P-value: } \\
\text { Cash=Food }\end{array}$ & $\begin{array}{c}\text { P-value: } \\
\text { Cash+BCC= } \\
\text { Food }+ \text { BCC }\end{array}$ \\
\hline Emotional violence (last6m) at $6 \mathrm{mPP}$ & 0.61 & $\begin{array}{l}-0.01 \\
(0.05)\end{array}$ & $\begin{array}{c}0.02 \\
(0.05)\end{array}$ & 0.46 & 0.63 & $\begin{array}{c}0.03 \\
(0.06)\end{array}$ & $\begin{array}{l}-0.05 \\
(0.05)\end{array}$ & 0.11 & 0.53 & 0.33 \\
\hline Emotional violence (last $12 \mathrm{~m}$ ) at $4 \mathrm{yPP}$ & 0.44 & $\begin{array}{c}0.02 \\
(0.04)\end{array}$ & $\begin{array}{l}-0.07 \\
(0.04)\end{array}$ & $0.03 * *$ & 0.40 & $\begin{array}{c}0.02 \\
(0.04)\end{array}$ & $\begin{array}{c}0.01 \\
(0.04)\end{array}$ & 0.80 & 0.97 & 0.19 \\
\hline Physical violence (last6m) at $6 \mathrm{mPP}$ & 0.30 & $\begin{array}{l}-0.01 \\
(0.03)\end{array}$ & $\begin{array}{l}-0.09 * * * \\
(0.04)\end{array}$ & $0.03 * *$ & 0.22 & $\begin{array}{c}0.01 \\
(0.03)\end{array}$ & $\begin{array}{l}-0.05 \\
(0.03)\end{array}$ & $0.10^{*}$ & 0.67 & 0.43 \\
\hline Physical violence (last $12 \mathrm{~m}$ ) at $4 \mathrm{yPP}$ & 0.26 & $\begin{array}{l}-0.03 \\
(0.03)\end{array}$ & $\begin{array}{l}-0.14 * * * \\
(0.03)\end{array}$ & $0.00 * * *$ & 0.17 & $\begin{array}{l}-0.02 \\
(0.03)\end{array}$ & $\begin{array}{l}-0.01 \\
(0.02)\end{array}$ & 0.53 & 0.85 & $0.00 * * *$ \\
\hline
\end{tabular}

Marginal effects of probit models reported. Controls of both models (North and South) include baseline characteristics of the woman and her household.

Standard errors clustered at the village level. $* \mathrm{p}<0.1 * * \mathrm{p}<0.05 ; * * * \mathrm{p}<0.01$ 
Table 7: 4-year post-program impact of treatment on IPV pathways, pooled North and South

\begin{tabular}{|c|c|c|c|c|}
\hline & $\mathrm{N}$ & Transfers & Transfers $+\mathrm{BCC}$ & $\begin{array}{c}\text { P-value of } \\
\text { Transfers= } \\
\text { Transfers+BCC }\end{array}$ \\
\hline Channel: Women's Economic resources & 2,416 & $\begin{array}{c}0.02 \\
(0.05)\end{array}$ & $\begin{array}{l}0.11^{*} \\
(0.06)\end{array}$ & $0.08 *$ \\
\hline Channel: Women's agency & 2,416 & $\begin{array}{r}0.04 \\
(0.06)\end{array}$ & $\begin{array}{c}0.17 * * \\
(0.07)\end{array}$ & $0.08^{*}$ \\
\hline Channel: Women's social and community support & 2,416 & $\begin{array}{r}0.03 \\
(0.07)\end{array}$ & $\begin{array}{c}0.11 \\
(0.07)\end{array}$ & 0.22 \\
\hline Channel: Perceived social control & 2,416 & $\begin{array}{r}0.00 \\
(0.11)\end{array}$ & $\begin{array}{l}0.16^{*} \\
(0.09)\end{array}$ & 0.13 \\
\hline Channel: Men's private costs & 1,989 & $\begin{array}{l}-0.03 \\
(0.06)\end{array}$ & $\begin{array}{r}0.00 \\
(0.06)\end{array}$ & 0.63 \\
\hline Channel: Household poverty & 2,416 & $\begin{array}{r}0.06 \\
(0.06)\end{array}$ & $\begin{array}{c}0.27 * * * \\
(0.07)\end{array}$ & $0.00 * * *$ \\
\hline Channel: Men's emotional well-being & 1,989 & $\begin{array}{r}0.07 \\
(0.07)\end{array}$ & $\begin{array}{l}0.14 * \\
(0.08)\end{array}$ & 0.39 \\
\hline
\end{tabular}

OLS coefficients reported with standard errors in parentheses (clustered at the village level). Channels are constructed following Kling et al. (2007) and standardized to the control group. As described in Section 2.2, women's social and community support can also be conceptualized as men's cost, however they were estimated separately here to allow for mutually exclusive channels. Controls include baseline characteristics of the woman and her household. * $\mathrm{p}<0.1{ }^{* *} \mathrm{p}<0.05$; *** $\mathrm{p}<0.01$ 
Table 8: 4-year post-program impact of treatment on IPV pathways, North vs. South

\begin{tabular}{|c|c|c|c|c|c|c|c|c|c|c|}
\hline & \multicolumn{4}{|c|}{ North } & \multicolumn{4}{|c|}{ South } & \multicolumn{2}{|c|}{ North versus South } \\
\hline & & & & & & & & & P-value: & P-value: \\
\hline & $\begin{array}{l}\text { Mean of } \\
\text { Control }\end{array}$ & Cash & $\mathrm{Cash}+\mathrm{BCC}$ & $\begin{array}{c}\text { P-value of } \\
\text { Cash }= \\
\text { Cash+BCC }\end{array}$ & $\begin{array}{l}\text { Mean of } \\
\text { Control }\end{array}$ & Food & Food + BCC & $\begin{array}{c}\text { P-value of } \\
\text { Food }= \\
\text { Food }+ \text { BCC }\end{array}$ & Cash $=$ Food & $\begin{array}{l}\text { Cash }+\mathrm{BCC}= \\
\text { Food }+\mathrm{BCC}\end{array}$ \\
\hline \multirow[t]{2}{*}{ Channel: Women's economic resources } & -0.07 & 0.11 & $0.19^{* *}$ & 0.25 & 0.06 & -0.08 & 0.02 & 0.19 & $0.07 *$ & 0.16 \\
\hline & & $(0.07)$ & $(0.08)$ & & & $(0.08)$ & $(0.09)$ & & & \\
\hline \multirow[t]{2}{*}{ Channel: Women's agency } & -0.18 & $0.19^{* *}$ & $0.25^{* * *}$ & 0.54 & 0.17 & -0.10 & 0.09 & $0.07 *$ & $0.03 * *$ & 0.28 \\
\hline & & $(0.09)$ & $(0.09)$ & & & $(0.09)$ & $(0.11)$ & & & \\
\hline \multirow[t]{2}{*}{ Channel: Women's social \& community support } & -0.04 & 0.09 & $0.24 * *$ & 0.17 & 0.04 & -0.04 & -0.00 & 0.65 & 0.37 & $0.09^{*}$ \\
\hline & & $(0.10)$ & $(0.11)$ & & & $(0.10)$ & $(0.10)$ & & & \\
\hline \multirow[t]{2}{*}{ Channel: Perceived social control } & 0.21 & -0.00 & 0.06 & 0.61 & -0.20 & 0.01 & $0.23 *$ & 0.17 & 0.97 & 0.34 \\
\hline & & $(0.12)$ & $(0.11)$ & & & $(0.17)$ & $(0.13)$ & & & \\
\hline \multirow[t]{2}{*}{ Channel: Men's private costs } & -0.08 & 0.03 & 0.12 & 0.27 & 0.08 & -0.08 & -0.13 & 0.60 & 0.37 & $0.05 * *$ \\
\hline & & $(0.09)$ & $(0.09)$ & & & $(0.08)$ & $(0.09)$ & & & \\
\hline \multirow[t]{2}{*}{ Channel: Household poverty } & -0.35 & $0.20^{* *}$ & $0.40^{* * *}$ & $0.03 * *$ & 0.33 & -0.10 & 0.15 & $0.01^{* *}$ & $0.01^{* *}$ & $0.06^{*}$ \\
\hline & & $(0.08)$ & $(0.09)$ & & & $(0.09)$ & $(0.09)$ & & & \\
\hline \multirow[t]{2}{*}{ Channel: Men's emotional well-being } & -0.06 & $0.18^{*}$ & $0.27 * *$ & 0.40 & 0.06 & -0.05 & -0.00 & 0.67 & 0.11 & $0.06^{*}$ \\
\hline & & $(0.11)$ & $(0.11)$ & & & $(0.09)$ & $(0.10)$ & & & \\
\hline
\end{tabular}

OLS coefficients reported with standard errors in parentheses (clustered at the village level). $\mathrm{N}=2416$ for all indices except for men's channels: private costs and emotional well-being (both $\mathrm{N}=1989$ ).

Controls include baseline characteristics of the woman and her household. * $\mathrm{p}<0.1{ }^{* *} \mathrm{p}<0.05 ;{ }^{* * *} \mathrm{p}<0.01$ 


\section{Figures}

Figure 1: Flow chart of estimation sample






\section{References}

Ahmed, Akhter, John Hoddinott, Shalini Roy, Esha Sraboni, Wahidur Quabili, and Amy Margolies.. 2016. Which Kinds of Social Safety Net Transfers Work Best for the Ultra Poor in Bangladesh? Operation and Impacts of the Transfer Modality Research Initiative. International Food Policy Research Institute: Dhaka, Bangladesh.

Aizer, Anna, Shari Eli, Joseph Ferrie, and Adriana Lleras Muney. 2016. “The Long-Run Impact of Cash Transfers to Poor Families." American Economic Review 106(4): 935-71.

Anderson, Michael L. 2008. "Multiple Inference and Gender Differences in the Effects of Early Intervention: A Reevaluation of the Abecedarian, Perry Preschool, and Early Training Projects." Journal of the American Statistical Association 103(484): 1481-95.

Araujo, Maria Caridad, Mariano Bosch, and Norbert Schady. 2016. Can Cash Transfers Help Households Escape an Inter-Generational Poverty Trap? NBER.

Baird, Sarah, Craig McIntosh, and Berk Özler. 2019. "When the Money Runs out: Do Cash Transfers Have Sustained Effects on Human Capital Accumulation?" Journal of Development Economics 140: 169-85.

Barham, Tania, Karen Macours, and John Maluccio. 2017. “Are Conditional Cash Transfers Fulfilling Their Promise? Schooling, Learning, and Earnings After 10 Years." CEPR Discussion Papers.

Behrman, Jere R., Susan W. Parker, and Petra E. Todd. 2015. "Do Conditional Cash Transfers for Schooling Generate Lasting Benefits?” Journal of Human Resources 46(1): 93-122.

Benjamini, Yoav, and Yosef Hochberg. 1995. "Controlling the False Discovery Rate: A Practical and Powerful Approach to Multiple Testing." Source Journal of the Royal Statistical Society. Series B (Methodological) 57(1): 289-300. 
Benjamini, Yoav, Abba M. Krieger, and Daniel Yekutieli. 2006. “Adaptive Linear Step-up

Procedures That Control the False Discovery Rate.” Biometrika 93(3): 491-507.

Bourey, Christine, Whitney Williams, Erin Elizabeth Bernstein, and Rob Stephenson. 2015. "Systematic Review of Structural Interventions for Intimate Partner Violence in Low- and Middle-Income Countries: Organizing Evidence for Prevention.” BMC Public Health 15(1): 1165.

Brody, Carinne M. et al. 2015. “Economic Self-Help Group Programs for Improving Women's Empowerment: A Systematic Review.” Campbell Systematic Reviews 11(19).

Buller, Ana Maria et al. 2018. "A Mixed-Method Review of Cash Transfers and Intimate Partner Violence in Low- and Middle-Income Countries." The World Bank Research Observer 33(2): 218-58.

Cain, Mead, Syeda Rokeya Khanam, and Shamsun Nahar. 1979. "Class, Patriarchy, and Women's Work in Bangladesh." Population and Development Review 5(3): 405-38.

Cash Learning Partnership. 2015. "Protection in Cash Based Interventions - Interviews with Richard Nunn and Lou Lasap.”

Devries, K M et al. 2013. "Global Health. The Global Prevalence of Intimate Partner Violence against Women." Science 340(Ci): 27-29.

Ellsberg, Mary et al. 2001. "Researching Domestic Violence Against Women: Methodological and Ethical Considerations." Studies in Family Planning 32(1): 1-16.

_. 2008. "Intimate Partner Violence and Women's Physical and Mental Health in the WHO Multi-Country Study on Women's Health and Domestic Violence: An Observational Study." The Lancet 371(9619): 1165-72. 
Ellsberg, Mary, and Lori Heise. 2005. Researching Violence against Women: A Practical Guide for Researchers and Activists. Geneva: World Health Organization, PATH.

Farmer, Amy, and Jill Tiefenthaler. 1997. “An Economic Analysis of Domestic Violence.” Review of Social Economy 55(3): 337-58.

Haushofer, Johannes, and Ernst Fehr. 2014. “On the Psychology of Poverty." Science 344: 86267.

Haushofer, Johannes, and Jeremy Shapiro. 2018. The Long-Term Impact of Unconditional Cash Transfers: Experimental Evidence from Kenya.

Hidrobo, Melissa, Amber Peterman, and Lori Heise. 2016. "The Effect of Cash, Vouchers, and Food Transfers on Intimate Partner Violence: Evidence from a Randomized Experiment in Northern Ecuador.” American Economic Journal: Applied Economics 8(3): 284-303.

Hoddinott, John, Ishita Ahmed, Akhter Ahmed, and Shalini Roy. 2017. Behavior Change Communication Activities Improve Infant and Young Child Nutrition Knowledge and Practice of Neighboring Non-Participants in a Cluster-Randomized Trial in Rural Bangladesh.

Hoynes, Hilary, Diane Whitmore Schanzenbach, and Douglas Almond. 2016. "Long-Run Impacts of Childhood Access to the Safety Net." American Economic Review 06(4): 90334.

Kapiga, Saidi et al. 2017. "Prevalence of Intimate Partner Violence and Abuse and Associated Factors among Women Enrolled into a Cluster Randomised Trial in Northwestern Tanzania.” BMC Public Health 17(1): 190.

Kling, Jeffrey, Jeffrey Liebman, and Lawrence Katz. 2007. "Experimental Analysis of Neighborhood Effects.” Econometrica 75(1): 83-119. 
Lee, David S. 2009. “Training, Wages, and Sample Selection: Estimating Sharp Bounds on Treatment Effects.” The Review of Economic Studies 76(3): 1071-1102.

Lentz, Erin C. 2018. “Complicating Narratives of Women's Food and Nutrition Insecurity: Domestic Violence in Rural Bangladesh.” World Development 104: 271-80.

Mani, Anandi, Sendhil Mullainathan, Eldar Shafir, and Jiaying Zhao. 2013. "Poverty Impedes Cognitive Function.” Science 341: 976-80.

Menon, Purnima et al. 2016. "Impacts on Breastfeeding Practices of At-Scale Strategies That Combine Intensive Interpersonal Counseling, Mass Media, and Community Mobilization: Results of Cluster-Randomized Program Evaluations in Bangladesh and Viet Nam” ed. David Osrin. PLOS Medicine 13(10): e1002159.

Mercy Corps. 2015. Cash Transfer Programming Toolkit.

Millán, Teresa Molina et al. 2019. "Long-Term Impacts of Conditional Cash Transfers: Review of the Evidence." The World Bank Research Observer 34(1): 119-59.

Panda, Pradeep, and Bina Agarwal. 2005. "Marital Violence, Human Development and Women's Property Status in India." World Development 33(5): 823-50.

Reynolds, William M. 1982. "Development of Reliable and Valid Short Forms of the MarloweCrowne Social Desirability Scale.” Journal of Clinical Psychology 38(1): 119-25.

Roy, Shalini, Melissa Hidrobo, John Hoddinott, and Akhter Ahmed. “Transfers, Behavior Change Communication, and Intimate Partner Violence: Post-Program Evidence from Rural Bangladesh.” The Review of Economics and Statistics: In press.

Stets, Jan E. 1991. "Cohabiting and Marital Aggression: The Role of Social Isolation.” Journal of Marriage and the Family 53(3): 669. 
Stoeffler, Quentin, Bradford F. Mills, and Patrick Premand. 2016. Poor Households' Productive Investments of Cash Transfers : Quasi-Experimental Evidence from Niger. Washington, D.C.

Tauchen, H V, A D Witte, and S K Long. 1991. "Domestic Violence: A Nonrandom Affair." International Economic Review 32(2): 491-511.

World Bank. 2019. The World Bank Shock Responsive Safety Net for Human Capital Project (P171346).

World Health Organization. 2001. Putting Women First: Ethical and Safety Recommendations for Research on Domestic Violence Against Women. Geneva.

Van Wyk, Judy A, Michael L Benson, Greer Litton, and Fox Alfred Demaris. 2003. "Detangling Individual-, Partner-, and Community-Level Correlates of Partner Violence.” Crime \& Delinquency 49(3): 412-38. 


\section{Appendices}

\section{Appendix A: Implementation of TMRI's cluster randomized control trial design}

To implement TMRI's cluster randomized control trial design, analogous sampling processes were followed in the North and in the South. In each region, five sub-districts (upazilas) were selected from a list of upazilas where, according to the 2010 Bangladesh Poverty Map prepared by the Bangladesh Bureau of Statistics, the proportion of households living below the lower poverty line in Bangladesh was 25 percent or more. All villages within these five upazilas were listed. Villages with fewer than 125 households or villages that were considered peri-urban were dropped. In each region, simple random sampling was used to assign 50 villages from this list to each of the four treatment groups and to the control group, and to assign 25 villages as reserve. In the 250 selected villages in each region, a village census was carried out, which collected information on household demographics, poverty indicators, and whether households were participating in social safety net and other targeted interventions. 


\section{Appendix B: Intimate partner violence questions and categorizations}

Emotional violence

1. Insulted you or made you feel bad about yourself?

2. Belittled or humiliated you in front of other people?

3. Done things to scare or intimidate you on purpose (e.g. by the way he looked at you, by yelling and smashing things)?

4. Threatened to hurt you or someone you care about?

Physical violence

1. Slapped you or thrown something at you that could hurt you?

2. Pushed you or shoved you or pulled your hair?

3. Hit you with his fist or with something else that could hurt you?

4. Kicked you, dragged you or beat you up?

5. Choked or burnt you on purpose?

6. Threatened to use or actually used a gun, knife or other weapon against you 


\section{Appendix C: Construction of summary indices for pathway channels}

We have 29 variables that contribute to our understanding of the channels and thus the pathways that led to a sustainable reduction in IPV four years after the TMRI ended; these are listed in Appendix Table 2. We aggregate these variables into channels through the construction of standardized summary indices following Kling, Liebman, and Katz (2007) and Banerjee et al. (2015). We also construct these summary indices using Inverse Covariance Weighting (ICW) (Anderson 2008) as a robustness check.

Following Kling, Liebman, and Katz (2007), the construction of summary indices consists of the following steps:

1. All outcomes are recoded so that higher values represent "better" outcomes.

2. Missing values for all outcomes are then imputed at the random assignment group mean (for respondents with at least one non-missing outcome).

3. We then convert all outcomes into standardized z-scores (i.e. effect sizes) by subtracting the control group mean and dividing by the control group standard deviation (SD). This is straightforward for binary and continuous outcomes. Categorical outcomes, however, need to be transformed first into discrete variables. Following Heath, Hidrobo, and Roy (2018) this is done by transforming categorical outcomes with $\mathrm{n}$ response options into $\mathrm{n}-1$ binary variables and then standardizing, summing up and averaging out the result into one outcome index. ${ }^{15}$ For instance, a question with the three response options "never/sometimes/most of the time" is transformed into two binary variables, one with " 1 = sometimes/most of the time" and another with " $1=$ most of the time". Note that after this transformation, the more values of 1 the respondent gives, the greater her respective outcome. We prefer this transformation to treating the categorical variables as continuous, which assumes a constant marginal effect of going from never to sometimes and from sometimes to most of the time. If the marginal effect of each change is indeed not constant, treating the categorical variable as continuous would throw away important information by weighting each incremental change equally.

\footnotetext{
${ }^{15}$ As an alternative, Item Response Theory (IRT) models can also be used to create a summary outcome measure based on a given set of sub-questions (items). To test if IRT models produce similar results to our approach, we estimated IRT indices by fitting IRT models to the underlying items and predicted the latent variable as the summary index. We then standardized each IRT index analogous to the approach described above by subtracting the control group mean and dividing by the control group standard deviation. The indices of both approaches were very similar numerically, with an average correlation of $\sim 0.8$. Since we did not observe substantial differences between both approaches - and to be consistent with the remaining aggregation steps - we decided to use the standardization method as described above and not the IRT-constructed indices.
} 
These n-1 binary variables are then transformed into standardized z-scores by subtracting the control group mean and dividing by the control group SD. We then take the average of all standardized zscores and standardize the results again. The same approach is used to construct single outcome measures out of multiple survey questions of the same module.

4. The summary index is then simply the equally weighted average of z-scores. This average is then again standardized to the control group using the control group mean and standard deviation. Since each summary index therefore has a mean of 0 and standard deviation of 1 for the control group, the treatment effect estimators can be interpreted as the effect size relative to the control group, with higher scores showing more beneficial outcomes.

We also construct summary indices using Inverse Covariance Weighting (ICW) as a robustness check (Anderson 2008). Instead of using equal weights, this approach weighs each index component by the sum of its row entries in the inverted variance-covariance matrix of the outcome variables in the respective outcome family. These weights maximize the amount of information captured in the covariance matrix by assigning higher weights to those index components with lower covariance than other components, i.e. to those with "new" information. Conversely, it assigns lower weights to index components with high covariances with other components. We standardize this weighted average again using the control group mean and standard deviation. 


\section{Appendix D: Robustness of main impacts to alternative measures of IPV}

Appendix Tables 5 and 6 explore whether results are robust to alternative ways of defining violence. We first look at the individual indicators that make up emotional and physical violence (Appendix Table 5). Of the 4 indicators that make up emotional violence, none are significant in the Transfers arm and 1 is significant in the Transfers $+\mathrm{BCC}$ arm. In particular, Transfers $+\mathrm{BCC}$ lead to a 5-percentage point reduction in the likelihood that a husband does something to scare or intimidate his wife. For physical violence, although differences between the Transfers and Transfers $+\mathrm{BCC}$ arms are not significant, the Transfers $+\mathrm{BCC}$ arm leads to significant reductions in 4 out of the 6 individual indicators while the Transfers arm leads to a significant reduction in only 1 out of the 6 indicators.

Appendix Table 6 examines whether there are impacts of Transfers or Transfers $+\mathrm{BCC}$ on the intensive margin. Two indicators are created: the additive frequency of violence, which sums up the frequency ( once $=1$, a few times $=2$, many $=3$ ) reported for each individual act of physical or emotional violence, respectively; and the maximum violence which considers the maximum frequency reported over all acts of physical or emotional violence, respectively. For emotional violence, there are significant impacts at $4 \mathrm{yPP}$ of the Transfers $+\mathrm{BCC}$ arm on the additive frequency and maximum frequency scale of 20 and 12 percent respectively compared to the control group mean. For physical violence at 4yPP, we find some significant impacts of the Transfers arm at the intensive margin, but larger and more highly significant impacts of the Transfers $+\mathrm{BCC}$ arm. These results are consistent with our findings reported in Table 5 that highly significant results are consistently found only in the Transfers+BCC arm for physical violence. 


\section{Appendix E: Testing for Social Desirability Bias}

We conduct robustness analyses of the main impact estimates to test for social desirability bias, i.e. the tendency to report an answer that survey respondents deem to be viewed favorably by others. Social desirability bias could affect our results if IPV was differentially underreported across our intervention arms. Underreporting IPV per se, however, does not necessarily bias the impact estimates. For instance, if IPV was equally underreported in all treatment and control groups, the overall prevalence of IPV would be underreported but the comparison among the groups would not be affected and would still produce valid impact estimates. In particular, for our results to be driven by social desirability bias, it would have to be the case that there was differential bias between the Transfers $+\mathrm{BCC}$ arms (specifically the Cash $+\mathrm{BCC}$ arm) and other arms, that is, the combination of Transfers $+\mathrm{BCC}$ caused women to perceive reporting physical violence as less socially desirable but Transfers only did not. We test this empirically.

To measure social desirability at 4yPP, we followed Menon et al. (2016) and administered a subset of five binary questions adapted from the short form of the Marlowe-Crowne social desirability scale (Reynolds 1982). We construct a social desirability score (SDS) by adding up all the socially desirable responses of the five questions. The SDS therefore ranges from 0-5, whereby an SDS of 0-2 is considered as a low score, 3 as medium score, 4 as high, and 5 as very high (Ibid.). In our data, the mean SDS is 2.87 $(\mathrm{SD}=1.13)$ with a Chronbach's alpha of 0.54 .

We compare the SDS across treatment arms to see whether the score significantly differs between the Transfers group, the Transfers+BCC group, and the control group (Appendix Table 10). We find no significant differences between either of the Transfers groups to the control group, nor between the two Transfers groups. The SDS is $2.82(\mathrm{SD}=1.12)$ in the Transfers group, $2.93(\mathrm{SD}=1.15)$ in the Transfers $+\mathrm{BCC}$ group and $2.87(\mathrm{SD}=1.13)$ in the control group. We note that the magnitude of the scores is similar to the findings of Menon et al. (2016) who report SDS between 2.82 and 2.91 in their study in rural Bangladesh.

Given that we find the impact estimates of IPV to be sensitive to the study region we also compare the scores across treatment arms separately in the North and the South (Appendix Table 11). In the South, the results show no significant difference. In the North, however, the score in the Transfers $+\mathrm{BCC}$ arm (i.e., the $\mathrm{Cash}+\mathrm{BCC}$ arm) is $6.3 \%$ higher than in the control group $(p=0.08)$. This suggests that women in the North may indeed have underreported IPV in the BCC arm but not in others. Given that this mirrors our finding that IPV impact estimates are strongest in the Transfers $+\mathrm{BCC}$ arm in the North, this suggests the possibility that these estimates could have been driven by differentially low reporting and not by differentially low prevalence of IPV. To test this, we followed Menon et al. (2016) and estimated our 
regression models with each of the main IPV outcomes as the dependent variables and interactions between the treatment arms and the SDS as independent variables. We estimated these interaction models for the pooled sample, i.e. North and South combined (Appendix Table 12), as well as separately by region (Appendix Tables 13 and 14).

At 4yPP, there is no evidence for a significant interaction between any of the groups and the SDS. At $6 \mathrm{mPP}$, we do find a few significant interactions for both emotional and physical violence, but only in the Transfers group and not in the Transfers+BCC group. Given this pattern of findings, we believe that social desirability is unlikely to drive our results. 


\section{Appendix tables}

\section{Appendix Table 1: Operationalization of pathways}

\begin{tabular}{|c|c|c|}
\hline Pathway & $\begin{array}{c}\text { Channel } \\
\text { (summary index) }\end{array}$ & $\begin{array}{l}\text { Outcome variables } \\
\text { (index components) }\end{array}$ \\
\hline \multirow{3}{*}{$\begin{array}{l}\text { Women's } \\
\text { bargaining } \\
\text { power }\end{array}$} & $\begin{array}{l}\text { Women's economic } \\
\text { resources }\end{array}$ & $\begin{array}{l}\text { 1. Woman works for cash, food, or asset accumulation; } \\
\text { 2. Monthly labor income index; } \\
\text { 3. Control over money needed to buy food, clothes, medicine, } \\
\text { or toiletries/cosmetics; } \\
\text { 4. Index for value of assets solely owned; } \\
\text { 5. Ownership of savings }\end{array}$ \\
\hline & Women's agency & $\begin{array}{l}\text { 6. Locus of control index; } \\
\text { 7. Self-ranking on 9-step ladder of having rights; } \\
\text { 8. Self-ranking on 9-step ladder of ability to change life; } \\
\text { 9. Perceive success/failure as own responsibility vs. destiny; } \\
\text { 10. Gender norms index; } \\
\text { 11. Attitudes about IPV; } \\
\text { 12. Exposure to places outside of home index; } \\
\text { 13. Ever using radio or TV; } \\
\text { 14. Ownership of mobile phone }\end{array}$ \\
\hline & $\begin{array}{l}\text { Women's social and } \\
\text { community support }\end{array}$ & $\begin{array}{l}\text { 15. Level of social capital: someone to help in time of need; } \\
\text { 16. Level of social capital: meeting with women to discuss } \\
\text { issues; } \\
\text { 17. How often do you see family or friends; } \\
\text { 18. Participation in savings group }\end{array}$ \\
\hline \multirow[t]{2}{*}{ Men's costs } & Perceived social control & $\begin{array}{l}\text { 19. Woman's level of perceived social cohesion; } \\
\text { 20. Women's perception that community would intervene in } \\
\text { cases of IPV; } \\
\text { 21. Village leader's perception that community disagrees with } \\
\text { justifying IPV; } \\
\text { 22. Village leader's perception that community would } \\
\text { intervene in cases of IPV }\end{array}$ \\
\hline & Men's private costs & $\begin{array}{l}\text { 23. Male's gender norms index; } \\
\text { 24. Male's attitudes about IPV }\end{array}$ \\
\hline \multirow{2}{*}{$\begin{array}{l}\text { Poverty-related } \\
\text { emotional well- } \\
\text { being }\end{array}$} & Household poverty & $\begin{array}{l}\text { 25. Total monthly household consumption per capita; } \\
\text { 26. Household Food Insecurity }\end{array}$ \\
\hline & Men's emotional well-being & $\begin{array}{l}\text { 27. Men's stress; } \\
\text { 28. Men's depression; } \\
\text { 29. Men's locus of control }\end{array}$ \\
\hline
\end{tabular}


Appendix Table 2: Outcome variables used to construct summary indices

\begin{tabular}{|c|c|c|}
\hline \# & Outcome variable & Details \\
\hline 1 & $\begin{array}{l}\text { Woman works for cash, food, } \\
\text { or asset accumulation }\end{array}$ & $\begin{array}{l}\text { Probability }(0 / 1) \text { that female respondent is doing work that brings in } \\
\text { cash, additional food, or allows to accumulate } \mathrm{HH} \text { assets }\end{array}$ \\
\hline 2 & Monthly labor income index & $\begin{array}{l}\text { Index as the average of two indicators: having non-zero labor income; } \\
\text { and having non-zero labor income above the median of the non-zero } \\
\text { control group. Index standardized to the control group. }\end{array}$ \\
\hline 3 & $\begin{array}{l}\text { Control over money needed to } \\
\text { buy: food, clothes, medicine, } \\
\text { toiletries/cosmetics }\end{array}$ & $\begin{array}{l}\text { Probability }(0 / 1) \text { that female respondent controls money to buy food, } \\
\text { clothes, medicine, and toiletries/cosmetics (requires yes responses to } \\
\text { all four items). }\end{array}$ \\
\hline 4 & $\begin{array}{l}\text { Value of solely owned assets } \\
\text { (index) }\end{array}$ & $\begin{array}{l}\text { Index as the average of two indicators: owning non-zero asset values; } \\
\text { and owning non-zero asset values above the median of the non-zero } \\
\text { control group asset value. Index standardized to the control group. }\end{array}$ \\
\hline 5 & Ownership of savings & $\begin{array}{l}\text { Probability }(0 / 1) \text { that the female respondent owns any savings of any } \\
\text { value. }\end{array}$ \\
\hline 6 & Locus of control index & $\begin{array}{l}\text { Index created using factor analysis and based on } 15 \text { categorical } \\
\text { questions of Levenson's agency scale (Levenson 1981). Index } \\
\text { standardized to the control group. }\end{array}$ \\
\hline 7 & $\begin{array}{l}\text { Self-ranking on 9-step ladder of } \\
\text { having rights (index) }\end{array}$ & $\begin{array}{l}\text { Self-ranking of having rights, ranging from "completely without } \\
\text { rights" (=1) to "a lot of power" (=9). Responses were recoded to a } \\
\text { standardized index using the approach described in Appendix C. }\end{array}$ \\
\hline 8 & $\begin{array}{l}\text { Self-ranking on 9-step ladder of } \\
\text { ability to change life (index) }\end{array}$ & $\begin{array}{l}\text { Self-ranking of ability to change own life, ranging from "totally unable } \\
\text { to change my life" }(=1) \text { to "full control over my own life" }(=9) \text {. } \\
\text { Responses were recoded to a standardized index using the approach } \\
\text { described in Appendix C. }\end{array}$ \\
\hline 9 & $\begin{array}{l}\text { Perceive success/failure as own } \\
\text { responsibility vs. destiny }\end{array}$ & $\begin{array}{l}1=\text { female respondent perceives success/failure in life as own } \\
\text { responsibility; } 0=\text { as destiny }\end{array}$ \\
\hline 10 & Gender norms index & $\begin{array}{l}\text { Based on } 8 \text { questions asking the female respondent to what extent she } \\
\text { agrees/disagrees with normative statements around gender. Responses } \\
\text { were recoded to a standardized index using the approach described in } \\
\text { Appendix C. }\end{array}$ \\
\hline
\end{tabular}




\begin{tabular}{|c|c|c|}
\hline 11 & Attitudes about IPV & $\begin{array}{l}\text { Based on } 5 \text { questions asking the female respondent if she thinks a } \\
\text { husband is justified in hitting or beating his wife in any of the } 5 \\
\text { situations described. Recoded to binary indicator with } 1= \\
\text { hitting/beating never justified. }\end{array}$ \\
\hline 12 & $\begin{array}{l}\text { Exposure to places outside of } \\
\text { home (index) }\end{array}$ & $\begin{array}{l}\text { Index based on } 7 \text { questions asking the female respondent how often } \\
\text { she visits or goes to certain places (bazaar, doctor, community } \\
\text { meetings, friends, family, etc.). Responses were recoded to a } \\
\text { standardized index using the approach described in Appendix C. }\end{array}$ \\
\hline 13 & Ever using radio or $\mathrm{TV}$ & $\begin{array}{l}1=\text { female respondent is using radio or TV (ranging from irregularly } \\
\text { to every day); } 0=\text { hardly/never. }\end{array}$ \\
\hline 14 & Ownership of mobile phone & $1=$ female respondent owns a mobile phone; $0=$ doesn't. \\
\hline 15 & $\begin{array}{l}\text { Level of social capital: } \\
\text { Someone to help in time of } \\
\text { need }\end{array}$ & $\begin{array}{l}\text { Probability }(0 / 1) \text { that the female respondent has someone to help in } \\
\text { time of need. Must answer yes to all four criteria: hosts for multiple } \\
\text { nights in necessary, helps financially/lends money, helps when } \\
\text { insufficient food at home, talks to you if you have problems. }\end{array}$ \\
\hline 16 & $\begin{array}{l}\text { Level of social capital: Meet } \\
\text { with women to discuss issues }\end{array}$ & $\begin{array}{l}\text { Probability (0/1) that the female respondent meets with women to } \\
\text { discuss issues related to the community, education, health, finances, } \\
\text { agriculture/livestock, issues specific to women, issues related to } \\
\text { nutrition (all yes). }\end{array}$ \\
\hline 17 & $\begin{array}{l}\text { How often do you see family or } \\
\text { friends (index) }\end{array}$ & $\begin{array}{l}\text { Index based on } 2 \text { questions asking the female respondent how often } \\
\text { she visits relatives (outside of her household) or friends. Responses } \\
\text { were recoded to a standardized index using the approach described in } \\
\text { Appendix C. }\end{array}$ \\
\hline 18 & Participation in savings group & $\begin{array}{l}1=\text { female respondent has participated in a savings group in the last } 12 \\
\text { months; } 0=\text { has not. }\end{array}$ \\
\hline 19 & $\begin{array}{l}\text { Women's level of perceived } \\
\text { social cohesion (index) }\end{array}$ & $\begin{array}{l}\text { Index based on } 4 \text { questions asking the female respondent whether } \\
\text { people in her community: look out for and help their neighbors; can be } \\
\text { trusted; know who she is; care about her. Responses were recoded to a } \\
\text { standardized index using the approach described in Appendix C. }\end{array}$ \\
\hline 20 & $\begin{array}{l}\text { Women's perception that } \\
\text { community would intervene in } \\
\text { cases of IPV (index) }\end{array}$ & $\begin{array}{l}\text { Index based on } 2 \text { questions asking the female respondent how likely it } \\
\text { is that someone in her community would intervene if s/he learned that } \\
\text { a man was (a) verbally or (b) physically abusing his wife at home. } \\
\text { Responses were recoded to a standardized index using the approach } \\
\text { described in Appendix C. }\end{array}$ \\
\hline
\end{tabular}




\begin{tabular}{|c|c|c|}
\hline 21 & $\begin{array}{l}\text { Village leader's perception that } \\
\text { community disagrees with } \\
\text { justifying IPV (index) }\end{array}$ & $\begin{array}{l}\text { Index based on } 1 \text { question asking the village leader if village members } \\
\text { would agree that a husband is justified in hitting/beating his wife in } \\
\text { some situations. Responses were recoded to a standardized index using } \\
\text { the approach described in Appendix C. }\end{array}$ \\
\hline 22 & $\begin{array}{l}\text { Village leader's perception that } \\
\text { community would intervene in } \\
\text { cases of IPV (index) }\end{array}$ & $\begin{array}{l}\text { Index based on } 1 \text { question asking the village leader how likely it is that } \\
\text { village members would intervene if s/he learned that a man was } \\
\text { physically abusing his wife at home. Responses were recoded to a } \\
\text { standardized index using the approach described in Appendix C. }\end{array}$ \\
\hline 23 & Male's gender norms index & $\begin{array}{l}\text { Based on } 8 \text { questions asking the male respondent to what extent he } \\
\text { agrees/disagrees with normative statements around gender. Responses } \\
\text { were recoded to a standardized index using the approach described in } \\
\text { Appendix C. }\end{array}$ \\
\hline 24 & Male's attitudes about IPV & $\begin{array}{l}\text { Based on } 5 \text { questions asking the male respondent if he thinks a } \\
\text { husband is justified in hitting or beating his wife in any of the } 5 \\
\text { situations described. Recoded to binary indicator with } 1= \\
\text { hitting/beating never justified. }\end{array}$ \\
\hline 25 & $\begin{array}{l}\text { Total monthly household } \\
\text { consumption (per capita) }\end{array}$ & $\begin{array}{l}\text { Total monthly household expenditure per capita in 2012/13 } \\
\text { Bangladeshi Taka (BDT), i.e. deflated to TMRI's baseline year. }\end{array}$ \\
\hline 26 & $\begin{array}{l}\text { Household Food Insecurity } \\
\text { (HFIAS score) }\end{array}$ & $\begin{array}{l}\text { Household Food Insecurity Access Scale (HFIAS) score, ranging from } \\
0-27 \text { (following USAID/FANTA guidelines). Higher values denote } \\
\text { more food insecurity. }\end{array}$ \\
\hline 27 & Men's stress (PSS score) & $\begin{array}{l}\text { Perceived Stress Score (PSS), ranging from 0-40 (following Cohen, } \\
\text { Kamarck, and Mermelstein 1983). Higher values denote more } \\
\text { perceived stress. }\end{array}$ \\
\hline 28 & $\begin{array}{l}\text { Men's depression (PHQ-9 } \\
\text { score) }\end{array}$ & $\begin{array}{l}\text { Depression Severity Score (PHQ-9), ranging from 0-27. Higher values } \\
\text { denote higher levels of depression. }\end{array}$ \\
\hline 29 & Men's locus of control (index) & $\begin{array}{l}\text { Index created using factor analysis and based on } 15 \text { categorical } \\
\text { questions of Levenson's agency scale (Levenson 1981). Index } \\
\text { standardized to the control group. }\end{array}$ \\
\hline
\end{tabular}


Appendix Table 3: Attrition from 6mPP $(\mathrm{N}=2,749)$ to sample with husband data at 4yPP $(\mathrm{N}=1,989)$

\begin{tabular}{|c|c|c|c|}
\hline & Full sample & North & South \\
\hline \multirow[t]{2}{*}{ Transfers } & 0.01 & -0.00 & 0.03 \\
\hline & $(0.03)$ & $(0.03)$ & $(0.04)$ \\
\hline \multirow[t]{2}{*}{ Transfers $+\mathrm{BCC}$} & -0.00 & 0.02 & -0.02 \\
\hline & $(0.03)$ & $(0.03)$ & $(0.04)$ \\
\hline \multirow[t]{2}{*}{ Constant/Control group } & 0.28 & 0.26 & 0.29 \\
\hline & $(0.02)^{* * *}$ & $(0.02)^{* * *}$ & $(0.03)^{* * *}$ \\
\hline$R^{2}$ & 0.00 & 0.00 & 0.00 \\
\hline$N$ & 2,749 & 1,374 & 1,375 \\
\hline P-value: Transfers $=$ Transfers $+B C C$ & 0.58 & 0.50 & 0.18 \\
\hline
\end{tabular}

OLS coefficients reported. Full sample model includes regional fixed effects (not shown).

Standard errors clustered at the village level. * $p<0.1 * * p<0.05 ; * * * p<0.01$

Appendix Table 4: Baseline characteristics of sample with husband data by intervention arm

\begin{tabular}{|c|c|c|c|c|c|c|c|}
\hline & \multirow[t]{2}{*}{$\mathrm{N}$} & \multicolumn{3}{|c|}{ Means } & \multicolumn{3}{|c|}{ P-value of diff. } \\
\hline & & Transfers & Transfers $+\mathrm{BCC}$ & Control & $\begin{array}{l}\text { Transfers } \\
\text {-Control }\end{array}$ & $\begin{array}{c}\text { Transfers }+\mathrm{BCC} \\
\text {-Control }\end{array}$ & $\begin{array}{c}\text { Transfers - } \\
\text { Transfers+BCC }\end{array}$ \\
\hline Female respondent's age & 1,989 & 27.40 & 27.07 & 27.31 & 0.82 & 0.55 & 0.41 \\
\hline Female respondent's education (yrs) & 1,989 & 3.11 & 3.29 & 3.47 & $0.09 *$ & 0.45 & 0.41 \\
\hline $1=$ Female respondent can read and write & 1,989 & 0.53 & 0.57 & 0.57 & 0.27 & 0.96 & 0.33 \\
\hline $1=$ Female respondent is spouse of $\mathrm{HH}$ head & 1,989 & 0.83 & 0.83 & 0.83 & 0.85 & 0.77 & 0.91 \\
\hline Number of children $0-5$ years of respondent & 1,989 & 1.38 & 1.33 & 1.37 & 0.84 & 0.32 & 0.23 \\
\hline Number of children $6-15$ years of respondent & 1,989 & 0.97 & 0.90 & 0.95 & 0.76 & 0.50 & 0.34 \\
\hline Household size & 1,989 & 5.20 & 5.18 & 5.30 & 0.34 & 0.26 & 0.81 \\
\hline$p$-value from joint $F$-test & & & & & 0.57 & 0.49 & 0.94 \\
\hline
\end{tabular}

P-values are reported from Wald tests on the equality of means of control and each treatment for each variable.

Standard errors are clustered at the village level. * $p<0.1 * * p<0.05 ; * * * p<0.01$ 
Appendix Table 5: 4-year post-program impact of treatment on individual IPV indicators (past 12 months), pooled North and South

\begin{tabular}{|c|c|c|c|c|c|}
\hline & $\mathrm{N}$ & $\begin{array}{l}\text { Mean of } \\
\text { Control }\end{array}$ & Transfers & $\begin{array}{c}\text { Transfers } \\
+ \text { BCC }\end{array}$ & $\begin{array}{c}\text { P-value of } \\
\text { Transfers }= \\
\text { Transfers }+ \\
\text { BCC }\end{array}$ \\
\hline \multicolumn{6}{|l|}{ Emotional violence } \\
\hline Insulted you or made you feel bad about yourself & 2,416 & 0.38 & $\begin{array}{l}0.01 \\
(0.03)\end{array}$ & $\begin{array}{l}-0.04 \\
(0.03)\end{array}$ & $0.08 *$ \\
\hline Belittled or humiliated you in front of other people & 2,416 & 0.21 & $\begin{array}{l}-0.02 \\
(0.02)\end{array}$ & $\begin{array}{l}-0.02 \\
(0.02)\end{array}$ & 0.98 \\
\hline Done things to scare or intimidate you on purpose & 2,416 & 0.18 & $\begin{array}{l}-0.02 \\
(0.02)\end{array}$ & $\begin{array}{l}-0.05^{* * *} \\
(0.02)\end{array}$ & 0.11 \\
\hline Threatened to hurt you or someone you care about & 2,416 & 0.01 & $\begin{array}{l}-0.00 \\
(0.00)\end{array}$ & $\begin{array}{l}-0.01 \\
(0.01)\end{array}$ & 0.27 \\
\hline \multicolumn{6}{|l|}{ Physical violence } \\
\hline Slapped you or thrown something at you that could hurt you & 2,416 & 0.20 & $\begin{array}{l}-0.04 * \\
(0.02)\end{array}$ & $\begin{array}{l}-0.06^{* * *} \\
(0.02)\end{array}$ & 0.18 \\
\hline Pushed you or shoved you or pulled your hair & 2,416 & 0.09 & $\begin{array}{l}-0.02 \\
(0.01)\end{array}$ & $\begin{array}{l}-0.03 * * \\
(0.01)\end{array}$ & 0.33 \\
\hline Hit you with his fist or with something else that could hurt you & 2,416 & 0.09 & $\begin{array}{l}-0.02 \\
(0.01)\end{array}$ & $\begin{array}{l}-0.03^{* * *} \\
(0.01)\end{array}$ & 0.24 \\
\hline Kicked you, dragged you or beat you up & 2,416 & 0.06 & $\begin{array}{l}-0.02 \\
(0.01)\end{array}$ & $\begin{array}{l}-0.02 * \\
(0.01)\end{array}$ & 0.79 \\
\hline Choked or burnt you on purpose & 2,416 & 0.01 & $\begin{array}{l}-0.00 \\
(0.00)\end{array}$ & $\begin{array}{l}-0.01 \\
(0.01)\end{array}$ & 0.31 \\
\hline $\begin{array}{l}\text { Threatened to use or actually used a gun, knife or other } \\
\text { weapon against you }\end{array}$ & 2,416 & 0.01 & $\begin{array}{l}-0.00 \\
(0.00)\end{array}$ & $\begin{array}{l}-0.01 \\
(0.00)\end{array}$ & 0.48 \\
\hline
\end{tabular}


Appendix Table 6: 4-year post-program impact of treatment on frequency of IPV in the past 12 months, pooled North and South

\begin{tabular}{|c|c|c|c|c|c|}
\hline & $\mathrm{N}$ & $\begin{array}{c}\text { Mean } \\
\text { of } \\
\text { Control }\end{array}$ & Transfers & Transfers $+\mathrm{BCC}$ & $\begin{array}{c}\text { P-value of } \\
\text { Transfers }= \\
\text { Transfers+BCC }\end{array}$ \\
\hline Additive frequency of emotional violence (0-12), last $12 \mathrm{~m}$ & 2,416 & 1.38 & $\begin{array}{l}-0.09 \\
(0.13)\end{array}$ & $\begin{array}{l}-0.27 * * \\
(0.12)\end{array}$ & 0.13 \\
\hline Additive frequency of physical violence (0-18), last $12 \mathrm{~m}$ & 2,416 & 0.75 & $\begin{array}{l}-0.20^{*} \\
(0.11)\end{array}$ & $\begin{array}{l}-0.31 * * * \\
(0.10)\end{array}$ & 0.21 \\
\hline Maximum freq. of any emotional violence (0-3), last $12 \mathrm{~m}$ & 2,416 & 0.73 & $\begin{array}{l}0.00 \\
(0.06)\end{array}$ & $\begin{array}{l}-0.09^{*} \\
(0.05)\end{array}$ & $0.08 *$ \\
\hline Maximum freq. of any physical violence (0-3), last $12 \mathrm{~m}$ & 2,416 & 0.35 & $\begin{array}{l}-0.06^{*} \\
(0.04)\end{array}$ & $\begin{array}{l}-0.14^{* * *} \\
(0.03)\end{array}$ & $0.02 * *$ \\
\hline
\end{tabular}

OLS coefficients reported with standard errors in parentheses (clustered at the village level). Controls include baseline characteristics of the woman and her household. * $p<0.1 * * p<0.05 ; * * * p<0.01$ 
Appendix Table 7: Lee Bounds; 4-year post program impact on IPV, pooled North and South

\begin{tabular}{|c|c|c|c|c|c|c|}
\hline & \multicolumn{3}{|c|}{$\begin{array}{c}\text { Emotional violence (last12m) at } \\
4 y \mathrm{PP}\end{array}$} & \multicolumn{3}{|c|}{$\begin{array}{c}\text { Physical violence (last12m) at } \\
4 y P P\end{array}$} \\
\hline & Beta & Upper & Lower & Beta & Upper & Lower \\
\hline Transfer vs. Control & $\begin{array}{c}0.01 \\
(0.03)\end{array}$ & $\begin{array}{c}0.02 \\
(0.03)\end{array}$ & $\begin{array}{c}0.01 \\
(0.03)\end{array}$ & $\begin{array}{l}-0.03 \\
(0.02)\end{array}$ & $\begin{array}{l}-0.01 \\
(0.02)\end{array}$ & $\begin{array}{l}-0.03 \\
(0.02)\end{array}$ \\
\hline$N$ & 1,608 & 1,594 & 1,595 & 1,608 & 1,594 & 1,595 \\
\hline Control Mean & 0.42 & 0.42 & 0.42 & 0.21 & 0.21 & 0.21 \\
\hline Transfer+BCC vs. Control & $\begin{array}{l}-0.03 \\
(0.03)\end{array}$ & $\begin{array}{l}-0.03 \\
(0.03)\end{array}$ & $\begin{array}{l}-0.03 \\
(0.03)\end{array}$ & $\begin{array}{l}-0.07 \\
(0.02)^{* *}\end{array}$ & $\begin{array}{c}-0.07 \\
(0.02)^{* *}\end{array}$ & $\begin{array}{l}-0.07 \\
(0.02)^{* *}\end{array}$ \\
\hline$N$ & 1,614 & 1,614 & 1,613 & 1,614 & 1,614 & 1,613 \\
\hline Control Mean & 0.42 & 0.42 & 0.42 & 0.21 & 0.21 & 0.21 \\
\hline Transfer $+\mathrm{BCC}$ vs. Transfer & $\begin{array}{l}-0.05 \\
(0.03)\end{array}$ & $\begin{array}{l}-0.04 \\
(0.03)\end{array}$ & $\begin{array}{l}-0.06 \\
(0.03)^{*}\end{array}$ & $\begin{array}{l}-0.04 \\
(0.02)^{*}\end{array}$ & $\begin{array}{l}-0.04 \\
(0.02)^{*}\end{array}$ & $\begin{array}{l}-0.06 \\
(0.02)^{* *}\end{array}$ \\
\hline$N$ & 1,610 & 1,597 & 1,596 & 1,610 & 1,597 & 1,596 \\
\hline Transfer Mean & 0.44 & 0.44 & 0.44 & 0.19 & 0.19 & 0.19 \\
\hline
\end{tabular}

Marginal effects of probit models reported. Extended controls include baseline characteristics of the woman and her household (not shown). Standard errors clustered at the village level. * $\mathrm{p}<0.1 * * \mathrm{p}<0.05 ; * * \mathrm{p}<0.01$

Appendix Table 8: Lee Bounds; 4-year post program impact on IPV, North

\begin{tabular}{|c|c|c|c|c|c|c|}
\hline & \multicolumn{3}{|c|}{$\begin{array}{c}\text { Emotional violence (last12m) at } \\
4 y \mathrm{PP}\end{array}$} & \multicolumn{3}{|c|}{$\begin{array}{c}\text { Physical violence (last12m) at } \\
4 y P P\end{array}$} \\
\hline & Beta & Upper & Lower & Beta & Upper & Lower \\
\hline Transfer vs. Control & $\begin{array}{c}0.02 \\
(0.04)\end{array}$ & $\begin{array}{c}0.02 \\
(0.04)\end{array}$ & $\begin{array}{c}0.02 \\
(0.04)\end{array}$ & $\begin{array}{l}-0.04 \\
(0.03)\end{array}$ & $\begin{array}{l}-0.04 \\
(0.03)\end{array}$ & $\begin{array}{l}-0.04 \\
(0.03)\end{array}$ \\
\hline$N$ & 797 & 795 & 794 & 797 & 795 & 794 \\
\hline Control Mean & 0.44 & 0.44 & 0.44 & 0.26 & 0.26 & 0.26 \\
\hline Transfer+BCC vs. Control & $\begin{array}{l}-0.07 \\
(0.04)\end{array}$ & $\begin{array}{l}-0.06 \\
(0.04)\end{array}$ & $\begin{array}{l}-0.08 \\
(0.04)\end{array}$ & $\begin{array}{l}-0.14 \\
(0.03)^{* *}\end{array}$ & $\begin{array}{l}-0.12 \\
(0.03)^{* *}\end{array}$ & $\begin{array}{l}-0.14 \\
(0.03)^{* *}\end{array}$ \\
\hline$N$ & 778 & 769 & 772 & 778 & 769 & 771 \\
\hline Control Mean & 0.44 & 0.44 & 0.44 & 0.26 & 0.26 & 0.26 \\
\hline Transfer+BCC vs. Transfer & $\begin{array}{c}-0.09 \\
(0.04)^{*}\end{array}$ & $\begin{array}{l}-0.08 \\
(0.04)\end{array}$ & $\begin{array}{l}-0.09 \\
(0.04)^{*}\end{array}$ & $\begin{array}{c}-0.10 \\
(0.03)^{* *}\end{array}$ & $\begin{array}{c}-0.10 \\
(0.03)^{* *}\end{array}$ & $\begin{array}{c}-0.12 \\
(0.03)^{* *}\end{array}$ \\
\hline$N$ & 787 & 781 & 783 & 787 & 782 & 780 \\
\hline Transfer Mean & 0.46 & 0.46 & 0.46 & 0.23 & 0.23 & 0.23 \\
\hline
\end{tabular}


Appendix Table 9: Lee Bounds; 4-year post program impact on IPV, South

\begin{tabular}{lcccccc}
\hline & \multicolumn{3}{c}{ Emotional violence (last12m) at } & \multicolumn{3}{c}{ Physical violence (last12m) at } \\
& \multicolumn{3}{c}{ 4yPP } & \multicolumn{3}{c}{ 4yPP } \\
& Beta & Upper & Lower & Beta & Upper & Lower \\
\hline \hline Transfer vs. Control & 0.01 & 0.02 & 0.00 & -0.02 & -0.01 & -0.02 \\
& $(0.04)$ & $(0.04)$ & $(0.04)$ & $(0.03)$ & $(0.03)$ & $(0.03)$ \\
$N$ & 811 & 806 & 804 & 811 & 806 & 805 \\
Control Mean & 0.40 & 0.40 & 0.40 & 0.17 & 0.17 & 0.17 \\
& & & & & & \\
Transfer+BCC vs. Control & 0.01 & 0.01 & 0.01 & -0.01 & -0.01 & -0.01 \\
& $(0.04)$ & $(0.04)$ & $(0.04)$ & $(0.02)$ & $(0.02)$ & $(0.02)$ \\
$N$ & 836 & 836 & 835 & 836 & 836 & 835 \\
Control Mean & 0.40 & 0.40 & 0.40 & 0.17 & 0.17 & 0.17 \\
& & & & & & \\
Transfer+BCC vs. Transfer & -0.01 & -0.00 & -0.03 & 0.01 & 0.02 & 0.00 \\
& $(0.04)$ & $(0.04)$ & $(0.04)$ & $(0.03)$ & $(0.03)$ & $(0.02)$ \\
$N$ & 823 & 816 & 813 & 823 & 815 & 816 \\
Transfer Mean & 0.41 & 0.41 & 0.41 & 0.14 & 0.14 & 0.14 \\
\hline
\end{tabular}

Marginal effects of probit models reported. Extended controls include baseline characteristics of the woman and her household (not shown) Standard errors clustered at the village level. $* \mathrm{p}<0.1 * * \mathrm{p}<0.05 ; * * \mathrm{p}<0.01$

Appendix Table 10: Social Desirability Score at 4-year post program regressed on treatment status, pooled North and South

\begin{tabular}{|c|c|c|c|c|c|}
\hline & $\mathrm{N}$ & $\begin{array}{c}\text { Mean } \\
\text { of } \\
\text { Control }\end{array}$ & Transfer & $\begin{array}{c}\text { Transfer } \\
+ \text { BCC }\end{array}$ & $\begin{array}{c}\text { P-value of } \\
\text { Transfer= } \\
\text { Transfer+BCC }\end{array}$ \\
\hline Social Desirability Score (0-5) & 2,416 & 2.87 & $\begin{array}{c}-0.05 \\
(0.08)\end{array}$ & $\begin{array}{c}0.06 \\
(0.08)\end{array}$ & 0.13 \\
\hline
\end{tabular}

Appendix Table 11: Social Desirability Score at 4-year post program regressed on treatment status, North vs. South

\begin{tabular}{|c|c|c|c|c|c|c|c|c|c|c|}
\hline & $\begin{array}{c}\text { Mean } \\
\text { of } \\
\text { Control }\end{array}$ & Cash & $\begin{array}{l}\text { North } \\
\text { Cash+BCC }\end{array}$ & $\begin{array}{c}\text { P-value of } \\
\text { Cash= } \\
\text { Cash+BCC }\end{array}$ & $\begin{array}{c}\text { Mean } \\
\text { of } \\
\text { Control }\end{array}$ & Food & $\begin{array}{l}\text { South } \\
\text { Food+BCC }\end{array}$ & $\begin{array}{l}\text { P-value of } \\
\text { Food= } \\
\text { Food }+ \text { BCC }\end{array}$ & $\begin{array}{c}\text { P-value: } \\
\text { Cash=Food }\end{array}$ & $\begin{array}{c}\text { P-value: } \\
\text { Cash+BCC= } \\
\text { Food }+ \text { BCC }\end{array}$ \\
\hline Social Desirability Score $(0-5)$ & 2.85 & $\begin{array}{c}0.08 \\
(0.10)\end{array}$ & $\begin{array}{c}0.18^{*} \\
(0.10)\end{array}$ & 0.31 & 2.90 & $\begin{array}{c}-0.18 \\
(0.11)\end{array}$ & $\begin{array}{l}-0.06 \\
(0.12)\end{array}$ & 0.26 & $0.09 *$ & 0.12 \\
\hline
\end{tabular}


Appendix Table 12: Testing for Social Desirability Bias at 4-year post program, pooled North and South

\begin{tabular}{lcccc}
\hline & $\begin{array}{c}\text { Emotional } \\
\text { violence } \\
(\text { last6m) } \\
\text { at } 6 \mathrm{mPP}\end{array}$ & $\begin{array}{c}\text { Emotional } \\
\text { violence } \\
(\text { last12m) } \\
\text { at 4yPP }\end{array}$ & $\begin{array}{c}\text { Physical } \\
\text { violence } \\
\text { (last6m) } \\
\text { at 6mPP }\end{array}$ & $\begin{array}{c}\text { Physical } \\
\text { violence } \\
\text { (last12m) } \\
\text { at 4yPP }\end{array}$ \\
\hline \hline Transfer (food or cash) & 0.01 & 0.01 & -0.00 & -0.03 \\
Transfer (food or cash) + BCC & $(0.04)$ & $(0.03)$ & $(0.02)$ & $(0.02)$ \\
& -0.02 & -0.03 & -0.07 & -0.06 \\
Transfer * SDS & $(0.04)$ & $(0.03)$ & $(0.02)^{* * *}$ & $(0.02)^{* * *}$ \\
Transfer+BCC * SDS & 0.05 & 0.00 & 0.02 & 0.03 \\
Social Desirability Score $(0-5)$ & $(0.03)^{*}$ & $(0.03)$ & $(0.02)$ & $(0.02)$ \\
& 0.00 & 0.03 & 0.01 & 0.02 \\
$N$ & $(0.03)$ & $(0.03)$ & $(0.02)$ & $(0.02)$ \\
& -0.02 & -0.09 & -0.01 & -0.05 \\
& $(0.02)$ & $(0.02)^{* * *}$ & $(0.01)$ & $(0.01)^{* * *}$ \\
& 2,416 & 2,416 & 2,416 & 2,416 \\
& 0.62 & 0.42 & 0.26 & 0.21 \\
\hline
\end{tabular}

Marginal effects of probit models reported. Controls include baseline characteristics of the woman and her household (not shown). Standard errors clustered at the village level and shown in parentheses. Demeaned Social Desirability Score (SDS) used for

the interaction terms (to be interpreted as the percentage point difference to the control group due to a one standard deviation increase in the SDS). ${ }^{*} \mathrm{p}<0.1 * * \mathrm{p}<0.05 ; * * \mathrm{p}<0.01$

Appendix Table 13: Testing for Social Desirability Bias at 4-year post program, North

\begin{tabular}{|c|c|c|c|c|}
\hline & $\begin{array}{c}\text { Emotional } \\
\text { violence } \\
\text { (last6m) } \\
\text { at } 6 \mathrm{mPP}\end{array}$ & $\begin{array}{c}\text { Emotional } \\
\text { violence } \\
\text { (last12m) } \\
\text { at } 4 \mathrm{yPP}\end{array}$ & $\begin{array}{l}\text { Physical } \\
\text { violence } \\
\text { (last6m) } \\
\text { at } 6 \mathrm{mPP}\end{array}$ & $\begin{array}{c}\text { Physical } \\
\text { violence } \\
\text { (last } 12 \mathrm{~m} \text { ) } \\
\text { at } 4 \mathrm{yPP}\end{array}$ \\
\hline Transfer (food or cash) & $\begin{array}{l}-0.02 \\
(0.05)\end{array}$ & $\begin{array}{c}0.03 \\
(0.04)\end{array}$ & $\begin{array}{l}-0.01 \\
(0.03)\end{array}$ & $\begin{array}{l}-0.03 \\
(0.03)\end{array}$ \\
\hline Transfer (food or cash) $+\mathrm{BCC}$ & $\begin{array}{c}0.02 \\
(0.05)\end{array}$ & $\begin{array}{l}-0.05 \\
(0.04)\end{array}$ & $\begin{array}{c}-0.09 \\
(0.04)^{* *}\end{array}$ & $\begin{array}{c}-0.13 \\
(0.03)^{* * *}\end{array}$ \\
\hline Transfer * SDS & $\begin{array}{c}0.08 \\
(0.04)^{* *}\end{array}$ & $\begin{array}{l}-0.03 \\
(0.04)\end{array}$ & $\begin{array}{c}0.06 \\
(0.03)^{*}\end{array}$ & $\begin{array}{c}0.02 \\
(0.03)\end{array}$ \\
\hline Transfer $+\mathrm{BCC} * \mathrm{SDS}$ & $\begin{array}{c}0.04 \\
(0.04)\end{array}$ & $\begin{array}{c}0.00 \\
(0.03)\end{array}$ & $\begin{array}{c}0.04 \\
(0.03)\end{array}$ & $\begin{array}{c}0.02 \\
(0.03)\end{array}$ \\
\hline Social Desirability Score $(0-5)$ & $\begin{array}{l}-0.04 \\
(0.03)^{*}\end{array}$ & $\begin{array}{c}-0.10 \\
(0.02)^{* * *}\end{array}$ & $\begin{array}{l}-0.03 \\
(0.02)^{*}\end{array}$ & $\begin{array}{c}-0.05 \\
(0.02)^{* * *}\end{array}$ \\
\hline$N$ & $\begin{array}{c}1,181 \\
0.61 \\
\end{array}$ & $\begin{array}{c}1,181 \\
0.44 \\
\end{array}$ & $\begin{array}{c}1,181 \\
0.30 \\
\end{array}$ & $\begin{array}{c}1,181 \\
0.26 \\
\end{array}$ \\
\hline
\end{tabular}

Marginal effects of probit models reported. Controls include baseline characteristics of the woman and her household (not shown). Standard errors clustered at the village level and shown in parentheses. Demeaned Social Desirability Score (SDS) used for the interaction terms (to be interpreted as the percentage point difference to the control group due to a one standard deviation increase in the SDS). ${ }^{*} \mathrm{p}<0.1 * * \mathrm{p}<0.05 ; * * * \mathrm{p}<0.01$ 
Appendix Table 14: Testing for Social Desirability Bias at 4-year post program, South

\begin{tabular}{lcccc}
\hline & $\begin{array}{c}\text { Emotional } \\
\text { violence } \\
\text { (last6m) } \\
\text { at 6mPP }\end{array}$ & $\begin{array}{c}\text { Emotional } \\
\text { violence } \\
\text { (last12m) } \\
\text { at 4yPP }\end{array}$ & $\begin{array}{c}\text { Physical } \\
\text { violence } \\
\text { (last6m) } \\
\text { at 6mPP }\end{array}$ & $\begin{array}{c}\text { Physical } \\
\text { violence } \\
\text { (last12m) } \\
\text { at 4yPP }\end{array}$ \\
\hline \hline Transfer (food or cash) & 0.04 & 0.01 & 0.01 & -0.02 \\
Transfer (food or cash) + BCC & $(0.06)$ & $(0.04)$ & $(0.03)$ & $(0.03)$ \\
Transfer * SDS & -0.05 & 0.00 & -0.04 & -0.00 \\
Transfer+BCC * SDS & $(0.05)$ & $(0.04)$ & $(0.03)$ & $(0.02)$ \\
Social Desirability Score $(0-5)$ & 0.03 & 0.03 & -0.02 & 0.04 \\
& $(0.04)$ & $(0.04)$ & $(0.03)$ & $(0.03)$ \\
$N$ & -0.04 & 0.06 & -0.02 & 0.03 \\
& $(0.04)$ & $(0.04)$ & $(0.03)$ & $(0.03)$ \\
& 0.01 & -0.07 & 0.01 & -0.05 \\
& $(0.03)$ & $(0.02)^{* * *}$ & $(0.02)$ & $(0.02)^{* * *}$ \\
& 1,235 & 1,235 & 1,235 & 1,235 \\
& 0.63 & 0.40 & 0.22 & 0.17 \\
\hline
\end{tabular}

Marginal effects of probit models reported. Controls include baseline characteristics of the woman and her household (not shown). Standard errors clustered at the village level and shown in parentheses. Demeaned Social Desirability Score (SDS) used for the interaction terms (to be interpreted as the percentage point difference to the control group due to a one standard deviation increase in the SDS). ${ }^{*} \mathrm{p}<0.1 * * \mathrm{p}<0.05 ; * * \mathrm{p}<0.01$ 
Appendix Table 15: 4-year post program impact of treatment on prevalence of IPV in past 12 months (multiple testing), pooled North and South

\begin{tabular}{|c|c|c|c|c|c|c|c|c|}
\hline & \multirow[b]{2}{*}{$\mathrm{N}$} & \multirow[b]{2}{*}{$\begin{array}{c}\text { Mean } \\
\text { of } \\
\text { Control }\end{array}$} & \multicolumn{3}{|c|}{ Basic controls } & \multicolumn{3}{|c|}{ Extended controls } \\
\hline & & & Transfers & Transfers $+\mathrm{BCC}$ & $\begin{array}{c}\text { P-value of } \\
\text { Transfers= } \\
\text { Transfers+BCC }\end{array}$ & Transfers & Transfers $+\mathrm{BCC}$ & $\begin{array}{c}\text { P-value of } \\
\text { Transfers }= \\
\text { Transfers }+ \text { BCC }\end{array}$ \\
\hline Emotional violence (last6m) at $6 \mathrm{mPP}$ & 2,416 & 0.62 & 0.01 & -0.02 & 0.44 & 0.01 & -0.02 & 0.42 \\
\hline Unadjusted p-value & & & 0.86 & 0.57 & & 0.85 & 0.57 & \\
\hline FDR-adj. p-value (BKY 2006) & & & 1.00 & 1.00 & & 0.99 & 0.89 & \\
\hline FDR-adj. p-value (BH 1995) & & & 0.98 & 0.76 & & 0.92 & 0.76 & \\
\hline Emotional violence (last $12 \mathrm{~m}$ ) at $4 \mathrm{yPP}$ & 2,416 & 0.42 & 0.02 & -0.03 & 0.11 & 0.02 & -0.03 & $0.08 *$ \\
\hline Unadjusted p-value & & & 0.53 & 0.33 & & 0.56 & 0.25 & \\
\hline FDR-adj. p-value (BKY 2006) & & & 1.00 & 0.98 & & 0.89 & 0.60 & \\
\hline FDR-adj. p-value (BH 1995) & & & 0.76 & 0.66 & & 0.76 & 0.50 & \\
\hline Physical violence (last6m) at $6 \mathrm{mPP}$ & 2,416 & 0.26 & 0.00 & -0.06 & $0.01 * *$ & -0.00 & -0.07 & $0.01 * *$ \\
\hline Unadjusted p-value & & & 0.98 & $0.01 * * *$ & & 0.92 & $0.01 * * *$ & \\
\hline FDR-adj. p-value (BKY 2006) & & & 1.00 & $0.03 * *$ & & 0.99 & $0.02 * *$ & \\
\hline FDR-adj. p-value (BH 1995) & & & 0.98 & $0.04 * *$ & & 0.92 & $0.02 * *$ & \\
\hline Physical violence (last $12 \mathrm{~m}$ ) at $4 \mathrm{yPP}$ & 2,416 & 0.21 & -0.03 & -0.06 & $0.08 *$ & -0.03 & -0.07 & $0.05 * *$ \\
\hline Unadjusted p-value & & & 0.22 & $0.00 * * *$ & & 0.17 & $0.00 * * *$ & \\
\hline FDR-adj. p-value (BKY 2006) & & & 0.79 & $0.02 * *$ & & 0.51 & $0.00 * * *$ & \\
\hline FDR-adj. p-value (BH 1995) & & & 0.59 & $0.02 * *$ & & 0.45 & $0.00 * * *$ & \\
\hline
\end{tabular}

${ }_{*} \mathrm{p}<0.1 * * \mathrm{p}<0.05 ; * * * \mathrm{p}<0.01$ 
Appendix Table 16: 4-year post program impact of treatment on prevalence of IPV in the past 12 months (multiple testing), North vs. South

\begin{tabular}{|c|c|c|c|c|c|c|c|c|c|c|}
\hline & \multicolumn{4}{|c|}{ North } & \multicolumn{4}{|c|}{ South } & \multicolumn{2}{|c|}{ North versus South } \\
\hline & $\begin{array}{c}\text { Mean } \\
\text { of } \\
\text { Control }\end{array}$ & Cash & $\mathrm{Cash}+\mathrm{BCC}$ & $\begin{array}{c}\text { P-value of } \\
\text { Cash }= \\
\text { Cash+BCC }\end{array}$ & $\begin{array}{c}\text { Mean } \\
\text { of } \\
\text { Control }\end{array}$ & Food & Food+BCC & $\begin{array}{l}\text { P-value of } \\
\text { Food }= \\
\text { Food+BCC }\end{array}$ & $\begin{array}{l}\text { P-value of } \\
\text { Cash=Food }\end{array}$ & $\begin{array}{c}\text { P-value of } \\
\text { Cash }+\mathrm{BCC}= \\
\text { Food }+\mathrm{BCC}\end{array}$ \\
\hline Emotional violence (last6m) at $6 \mathrm{mPP}$ & 0.61 & -0.01 & 0.02 & 0.46 & 0.63 & 0.03 & -0.05 & 0.11 & 0.53 & 0.33 \\
\hline Unadjusted p-value & & 0.77 & 0.69 & & & 0.57 & 0.34 & & & \\
\hline FDR-adj. p-value (BKY 2006) & & 0.92 & 0.92 & & & 1.00 & 1.00 & & & \\
\hline FDR-adj. p-value (BH 1995) & & 0.77 & 0.77 & & & 0.88 & 0.88 & & & \\
\hline $\begin{array}{l}\text { Emotional violence (last } 12 \mathrm{~m} \text { ) at } \\
4 \mathrm{yPP}\end{array}$ & 0.44 & 0.02 & -0.07 & $0.03 * *$ & 0.40 & 0.02 & 0.01 & 0.80 & 0.97 & 0.19 \\
\hline Unadjusted p-value & & 0.63 & 0.10 & & & 0.69 & 0.88 & & & \\
\hline FDR-adj. p-value (BKY 2006) & & 0.92 & 0.25 & & & 1.00 & 1.00 & & & \\
\hline FDR-adj. p-value (BH 1995) & & 0.77 & 0.27 & & & 0.88 & 0.88 & & & \\
\hline Physical violence (last6m) at $6 \mathrm{mPP}$ & 0.30 & -0.01 & -0.09 & $0.03 * *$ & 0.22 & 0.01 & -0.05 & $0.10^{*}$ & 0.67 & 0.43 \\
\hline Unadjusted p-value & & 0.73 & $0.01 * * *$ & & & 0.79 & 0.17 & & & \\
\hline FDR-adj. p-value (BKY 2006) & & 0.92 & $0.04 * *$ & & & 1.00 & 1.00 & & & \\
\hline FDR-adj. p-value (BH 1995) & & 0.77 & $0.04 * *$ & & & 0.88 & 0.88 & & & \\
\hline Physical violence (last $12 \mathrm{~m}$ ) at $4 \mathrm{yPP}$ & 0.26 & -0.03 & -0.14 & $0.00 * * *$ & 0.17 & -0.02 & -0.01 & 0.53 & 0.85 & $0.00 * * *$ \\
\hline Unadjusted p-value & & 0.27 & $0.00 * * *$ & & & 0.38 & 0.79 & & & \\
\hline FDR-adj. p-value (BKY 2006) & & 0.50 & $0.00 * * *$ & & & 1.00 & 1.00 & & & \\
\hline FDR-adj. p-value (BH 1995) & & 0.53 & $0.00 * * *$ & & & 0.88 & 0.88 & & & \\
\hline
\end{tabular}




\section{Appendix Table 17: 4-year post-program impact of treatment on IPV pathways (restricted sample),}

pooled North and South

\begin{tabular}{|c|c|c|c|c|}
\hline & $\mathrm{N}$ & Transfers & Transfers $+\mathrm{BCC}$ & $\begin{array}{c}\text { P-value of } \\
\text { Transfers= } \\
\text { Transfers+BCC }\end{array}$ \\
\hline Channel: Women's Economic resources & 1,989 & $\begin{array}{l}-0.00 \\
(0.06)\end{array}$ & $\begin{array}{l}0.11^{*} \\
(0.07)\end{array}$ & $0.07 *$ \\
\hline Channel: Women's agency & 1,989 & $\begin{array}{c}0.06 \\
(0.07)\end{array}$ & $\begin{array}{l}0.15 * * \\
(0.08)\end{array}$ & 0.20 \\
\hline Channel: Women's social and community support & 1,989 & $\begin{array}{l}0.02 \\
(0.08)\end{array}$ & $\begin{array}{l}0.11 \\
(0.08)\end{array}$ & 0.28 \\
\hline Channel: Perceived social control & 1,989 & $\begin{array}{c}0.01 \\
(0.11)\end{array}$ & $\begin{array}{l}0.16^{*} \\
(0.09)\end{array}$ & 0.17 \\
\hline Channel: Men's private costs & 1,989 & $\begin{array}{l}-0.03 \\
(0.06)\end{array}$ & $\begin{array}{l}0.00 \\
(0.06)\end{array}$ & 0.63 \\
\hline Channel: Household poverty & 1,989 & $\begin{array}{c}0.05 \\
(0.07)\end{array}$ & $\begin{array}{l}0.25^{* * *} \\
(0.07)\end{array}$ & $0.01 * * *$ \\
\hline Channel: Men's emotional well-being & 1,989 & $\begin{array}{c}0.07 \\
(0.07)\end{array}$ & $\begin{array}{l}0.14^{*} \\
(0.08)\end{array}$ & 0.39 \\
\hline
\end{tabular}

OLS coefficients reported with standard errors in parentheses (clustered at the village level). Channels are constructed following Kling et al. (2007) and standardized to the

control group. Controls include baseline characteristics of the woman and her household. $* \mathrm{p}<0.1 * * \mathrm{p}<0.05 ; * * * \mathrm{p}<0.01$ 
Appendix Table 18: 4-year post-program impact of treatment on IPV pathways (ICW), pooled North and South

\begin{tabular}{|c|c|c|c|c|}
\hline & $\mathrm{N}$ & Transfers & Transfers $+\mathrm{BCC}$ & $\begin{array}{c}\text { P-value of } \\
\text { Transfers }= \\
\text { Transfers }+ \text { BCC }\end{array}$ \\
\hline Channel: Women's Economic resources & 2,416 & $\begin{array}{c}0.02 \\
(0.05)\end{array}$ & $\begin{array}{l}0.11^{*} \\
(0.06)\end{array}$ & $0.10^{*}$ \\
\hline Channel: Women's agency & 2,416 & $\begin{array}{c}0.05 \\
(0.07)\end{array}$ & $\begin{array}{l}0.15^{* *} \\
(0.07)\end{array}$ & 0.15 \\
\hline Channel: Women's social and community support & 2,416 & $\begin{array}{c}0.02 \\
(0.07)\end{array}$ & $\begin{array}{c}0.11 \\
(0.07)\end{array}$ & 0.23 \\
\hline Channel: Perceived social control & 2,416 & $\begin{array}{l}-0.00 \\
(0.12)\end{array}$ & $\begin{array}{l}0.17 * \\
(0.10)\end{array}$ & 0.15 \\
\hline Channel: Men's private costs & 1,989 & $\begin{array}{l}-0.03 \\
(0.06)\end{array}$ & $\begin{array}{c}0.00 \\
(0.06)\end{array}$ & 0.60 \\
\hline Channel: Household poverty & 2,416 & $\begin{array}{c}0.06 \\
(0.06)\end{array}$ & $\begin{array}{l}0.26^{* * *} \\
(0.07)\end{array}$ & $0.00 * * *$ \\
\hline Channel: Men's emotional well-being & 1,989 & $\begin{array}{c}0.08 \\
(0.07)\end{array}$ & $\begin{array}{l}0.14 * \\
(0.07)\end{array}$ & 0.44 \\
\hline
\end{tabular}


Appendix Table 19: 4-year post program impact of treatment on IPV pathways, North vs. South

\begin{tabular}{|c|c|c|c|c|c|c|c|c|c|c|}
\hline & \multicolumn{4}{|c|}{ North } & \multicolumn{4}{|c|}{ South } & \multicolumn{2}{|c|}{ North versus South } \\
\hline & $\begin{array}{c}\text { Mean } \\
\text { of } \\
\text { Control }\end{array}$ & Cash & Cash+BCC & $\begin{array}{c}\text { P-value of } \\
\text { Cash= } \\
\text { Cash+BCC }\end{array}$ & $\begin{array}{c}\text { Mean } \\
\text { of } \\
\text { Control }\end{array}$ & Food & Food + BCC & $\begin{array}{c}\text { P-value of } \\
\text { Food= } \\
\text { Food+BCC }\end{array}$ & $\begin{array}{l}\text { P-value of } \\
\text { Cash=Food }\end{array}$ & $\begin{array}{c}\text { P-value of } \\
\text { Cash }+ \text { BCC }= \\
\text { Food }+ \text { BCC }\end{array}$ \\
\hline $\begin{array}{l}\text { Channel: Women's economic } \\
\text { resources }\end{array}$ & -0.07 & 0.11 & 0.19 & 0.25 & 0.06 & -0.08 & 0.02 & 0.19 & $0.07 *$ & 0.16 \\
\hline Unadjusted p-value & & 0.13 & $0.02 * *$ & & & 0.27 & 0.78 & & & \\
\hline FDR-adj. p-value (BKY 2006) & & 0.12 & $0.05 *$ & & & 1.00 & 1.00 & & & \\
\hline FDR-adj. p-value (BH 1995) & & 0.21 & $0.05 *$ & & & 0.66 & 0.99 & & & \\
\hline Channel: Women's agency & -0.18 & 0.19 & 0.25 & 0.54 & 0.17 & -0.10 & 0.09 & $0.07 *$ & $0.03 * *$ & 0.28 \\
\hline Unadjusted p-value & & $0.03 * *$ & $0.01 * * *$ & & & 0.29 & 0.38 & & & \\
\hline FDR-adj. p-value (BKY 2006) & & $0.05^{*}$ & $0.05 *$ & & & 1.00 & 1.00 & & & \\
\hline FDR-adj. p-value (BH 1995) & & $0.06^{*}$ & $0.05 *$ & & & 0.66 & 0.66 & & & \\
\hline $\begin{array}{l}\text { Channel: Women's social and } \\
\text { community support }\end{array}$ & -0.04 & 0.09 & 0.24 & 0.17 & 0.04 & -0.04 & -0.00 & 0.65 & 0.37 & $0.09 *$ \\
\hline Unadjusted p-value & & 0.40 & $0.02 * *$ & & & 0.67 & 0.98 & & & \\
\hline FDR-adj. p-value (BKY 2006) & & 0.26 & $0.05^{*}$ & & & 1.00 & 1.00 & & & \\
\hline FDR-adj. p-value (BH 1995) & & 0.51 & $0.06^{*}$ & & & 0.93 & 0.99 & & & \\
\hline Channel: Perceived social control & 0.21 & -0.00 & 0.06 & 0.61 & -0.20 & 0.01 & 0.23 & 0.17 & 0.97 & 0.34 \\
\hline Unadjusted p-value & & 0.99 & 0.58 & & & 0.97 & $0.09 *$ & & & \\
\hline FDR-adj. p-value (BKY 2006) & & 0.40 & 0.32 & & & 1.00 & 1.00 & & & \\
\hline FDR-adj. p-value (BH 1995) & & 0.99 & 0.68 & & & 0.99 & 0.66 & & & \\
\hline Channel: Men's private cost & -0.08 & 0.03 & 0.12 & 0.27 & 0.08 & -0.08 & -0.13 & 0.60 & 0.37 & $0.05 * *$ \\
\hline Unadjusted $\mathrm{p}$-value & & 0.75 & 0.19 & & & 0.34 & 0.15 & & & \\
\hline FDR-adj. p-value (BKY 2006) & & 0.35 & 0.15 & & & 1.00 & 1.00 & & & \\
\hline FDR-adj. p-value (BH 1995) & & 0.81 & 0.26 & & & 0.66 & 0.66 & & & \\
\hline Channel: Household poverty & -0.35 & 0.20 & 0.40 & $0.03 * *$ & 0.33 & -0.10 & 0.15 & $0.01 * *$ & $0.01 * *$ & $0.06^{*}$ \\
\hline Unadjusted p-value & & $0.02 * *$ & $0.00 * * *$ & & & 0.27 & 0.12 & & & \\
\hline FDR-adj. p-value (BKY 2006) & & $0.05^{*}$ & $0.00 * * *$ & & & 1.00 & 1.00 & & & \\
\hline FDR-adj. p-value (BH 1995) & & $0.05 *$ & $0.00 * * *$ & & & 0.66 & 0.66 & & & \\
\hline $\begin{array}{l}\text { Channel: Men's emotional well- } \\
\text { being }\end{array}$ & -0.06 & 0.18 & 0.27 & 0.40 & 0.06 & -0.05 & -0.00 & 0.67 & 0.11 & $0.06^{*}$ \\
\hline Unadjusted p-value & & $0.09 *$ & $0.01 * *$ & & & 0.62 & 0.99 & & & \\
\hline FDR-adj. p-value (BKY 2006) & & $0.09 *$ & $0.05 *$ & & & 1.00 & 1.00 & & & \\
\hline FDR-adj. p-value (BH 1995) & & 0.16 & $0.05 *$ & & & 0.93 & 0.99 & & & \\
\hline
\end{tabular}

OLS coefficients reported with standard errors clustered at the village level (not shown). $\mathrm{N}=2416$ for all indices except private costs and emotional well-being of men (both $\mathrm{N}=1989$ ).

Controls include baseline characteristics of the woman and her household. ${ }^{*} p<0.1 * * p<0.05 ; * * * p<0.01$ 


\section{Appendix references}

Anderson, Michael L. 2008. "Multiple Inference and Gender Differences in the Effects of Early Intervention: A Reevaluation of the Abecedarian, Perry Preschool, and Early Training Projects." Journal of the American Statistical Association 103(484): 1481-95.

Banerjee, Abhijit, Esther Duflo, Nathanael Goldberg, Dean Karlan, Robert Osei, William Parienté, Jeremy Shapiro, Bram Thuysbaert, and Christopher Udry. 2015. “A Multifaceted Program Causes Lasting Progress for the Very Poor: Evidence from Six Countries.” Science 348(6236): 1260799.

Cohen, Sheldon, Tom Kamarck, and Robin Mermelstein. 1983. "A Global Measure of Perceived Stress." Journal of Health and Social Behavior 24: 385- 396.

Heath, Rachel, Melissa Hidrobo, and Shalini Roy. 2018. "Cash Transfers, Polygamy, and Intimate Partner Violence: Experimental Evidence from Mali.” IFPRI Discussion Paper 01785.

Kling, Jeffrey, Jeffrey Liebman, and Lawrence Katz. 2007. "Experimental Analysis of Neighborhood Effects." Econometrica 75(1): 83-119.

Levenson, Hanna. 1981. “Differenciating among Internality, Powerful Others, and Chance.” In Research with the Locus of Control Construct, ed. Herbert M B T - Research with the Locus of Control Construct Lefcourt. Academic Press, 15-63.

Menon, Purnima, Phuong Hong Nguyen, Kuntal Kumar Saha, Adiba Khaled, Andrew Kennedy, Lan Mai Tran, Tina Sanghvi, Nemat Hajeebhoy, Jean Baker, Silvia Alayon, Kaosar Afsana, Raisul Haque, Edward A. Frongillo, Marie T. Ruel, and Rahul Rawat. 2016. "Impacts on Breastfeeding Practices of At-Scale Strategies That Combine Intensive Interpersonal Counseling, Mass Media, and Community Mobilization: Results of Cluster-Randomized Program Evaluations in Bangladesh and Viet Nam” ed. David Osrin. PLOS Medicine 13(10): e1002159.

Reynolds, William M. 1982. "Development of Reliable and Valid Short Forms of the Marlowe-Crowne Social Desirability Scale.” Journal of Clinical Psychology 38(1): 119-25. 


\section{ALL IFPRI DISCUSSION PAPERS}

All discussion papers are available here

They can be downloaded free of charge

INTERNATIONAL FOOD POLICY RESEARCH INSTITUTE

www.ifpri.org

\section{IFPRI HEADQUARTERS}

1201 Eye Street, NW

Washington, DC 20005 USA

Tel.: +1-202-862-5600

Fax: +1-202-862-5606

Email: ifpri@cgiar.org 